NBER WORKING PAPER SERIES

\title{
SHAPED BY BOOMS AND BUSTS: \\ HOW THE ECONOMY IMPACTS CEO CAREERS AND MANAGEMENT STYLES
}

\author{
Antoinette Schoar \\ Luo Zuo \\ Working Paper 17590 \\ http://www.nber.org/papers/w17590 \\ NATIONAL BUREAU OF ECONOMIC RESEARCH \\ 1050 Massachusetts Avenue \\ Cambridge, MA 02138 \\ November 2011
}

We appreciate the helpful comments of Francesca Cornelli (editor), three anonymous referees, Joshua Anderson, Philip Berger, Qi Chen, Jess Cornaggia, Sudipto Dasgupta, Mei Feng, Robert Gibbons, Dirk Jenter, Bin Ke, Leonid Kogan, Camelia Kuhnen, Masatoshi Kurusu, Jing Liu, Evgeny Lyandres, Mark Maffett, Randall Morck, Sendhil Mullainathan, Kasper Meisner Nielsen, Dimitris Papanikolaou, Francisco Pérez-González, Morten Sorensen, T.J. Wong, Bernard Yeung, Weining Zhang, and seminar participants at Cheung Kong Graduate School of Business, the Massachusetts Institute of Technology, Xi' an Jiaotong University, the NBER Corporate Finance Meeting, the 2012 Western Finance Association Annual Meeting, the 2012 IZA Workshop on Economics of Leadership, the 2012 American Accounting Association Annual Meeting, the 2013 China International Conference in Finance, the 2013 MIT Asia Conference in Accounting, the 2014 Tsinghua International Corporate Governance Conference, and the 2016 American Economic Association Annual Meeting. We acknowledge financial support from the MIT Sloan School of Management. Luo Zuo is also grateful for financial support from Cornell University and the Deloitte Foundation. Selva Swetha Ayyampalayam Rajeswaran, Sharon Bureau, Kate Gordon, Edan Krolewicz, and Cynthia Wang provided outstanding research assistance. The views expressed herein are those of the authors and do not necessarily reflect the views of the National Bureau of Economic Research.

NBER working papers are circulated for discussion and comment purposes. They have not been peer-reviewed or been subject to the review by the NBER Board of Directors that accompanies official NBER publications.

(C) 2011 by Antoinette Schoar and Luo Zuo. All rights reserved. Short sections of text, not to exceed two paragraphs, may be quoted without explicit permission provided that full credit, including $(\odot$ notice, is given to the source. 
Shaped by Booms and Busts: How the Economy Impacts CEO Careers and Management Styles Antoinette Schoar and Luo Zuo

NBER Working Paper No. 17590

November 2011, Revised February 2017

JEL No. D21,D23,G3,G31,G32

\begin{abstract}
We show that economic conditions when managers enter the labor market have long-run effects on their career paths and managerial styles. Managers who began their careers during recessions become CEOs more quickly, but at smaller firms. They also have more conservative styles, such as lower investment in capital expenditures and research and development, more cost cutting, and lower leverage and working capital needs. These recession effects appear to be largely driven by the characteristics of the CEO's first job (recession CEOs tend to start in smaller or private firms), which suggests that the early work environment is important to the formation and selection of managers.
\end{abstract}

\author{
Antoinette Schoar \\ MIT Sloan School of Management \\ 100 Main Street, E62-638 \\ Cambridge, MA 02142 \\ and NBER \\ aschoar@mit.edu \\ Luo Zuo \\ Johnson Graduate School of Management \\ Cornell University \\ 114 East Avenue \\ 349 Sage Hall \\ Ithaca, NY 14853 \\ luozuo@cornell.edu
}


A growing literature in finance and economics aims to understand the role that CEOs and other top managers play in the firms they run (see Bertrand 2009 for a review). Traditional theories about firm decisions such as capital structure or investments abstract away from the role of CEOs or assume that rational managers will behave identically if faced with the same problem. However, the more recent literature suggests that CEOs are heterogeneous and matter to the firms that they run. Several papers have shown substantial changes in a firm's stock price and accounting performance with top management turnovers (e.g., Warner, Watts, and Wruck 1989; Weisbach 1995; Pérez-González 2006; Bennedsen et al. 2007). To tie these results to individual heterogeneity, Bertrand and Schoar (2003) show that top executives have large and persistent person-specific differences in their management styles. There is also growing evidence that a CEO’s specific traits play a role in her management approach (e.g., Malmendier and Tate 2008; Kaplan, Klebanov, and Sorensen 2012; Graham, Harvey, and Puri 2013; Benmelech and Frydman 2015). ${ }^{1}$

However, much less is known about how these management styles are formed. Are they affected by conditions outside a manager's control, such as early career experiences? Or are they endogenously chosen in equilibrium by managers who seek to invest in the skill set that promises the highest returns over their careers, given their idiosyncratic personal characteristics? Alternatively, do different types of people select to become managers depending on the initial economic environment? If early work environment is indeed important to managerial styles, it points to the fact that at least a portion of a manager's style is fixed long before the manager becomes CEO. As a result, over the long run, macroeconomic factors might shape the available talent pool in the CEO labor market.

\footnotetext{
${ }^{1}$ Similarly, a large literature in management science has looked at the role of CEOs (e.g., Kotter 1982; Hambrick and Mason 1984; Fligstein 1990; Khurana 2002; Lazear 2004).
} 
To shed light on these questions, we look at labor market conditions at the beginning of a manager's career-that is, recessions versus non-recessions. To avoid endogenous selection of when an individual chooses to enter the labor market, we proxy for the exogenous starting date by using the manager's birth year plus 24 , the modal age of starting the first position over our sample.

Since labor market conditions are outside a person's control, it allows us to test whether CEOs who began their careers during a recession have a different career trajectory and ultimately a different management style as CEO. In particular, we want to understand the channel through which these different outcomes are formed. On the one hand is the idea that embarking on a career in a recession environment teaches young managers different skills or attitudes, irrelevant of the type of firm where their careers begin. Even if there are no changes in managers' early job allocations, during a recession firms and markets might predominantly expose a young manager to managerial techniques that preserve resources or cut costs. We call this the general recession channel. Under this scenario, we would expect to estimate a general recession cohort effect independent of where a manager's career begins.

On the other hand, recessions might affect managers via changes in labor markets during recession periods. Young managers might find it difficult to get jobs with traditional employers and might, in consequence, start their careers at smaller or private firms; or managers in these non-traditional firms might find it easier to get promoted during a recession. The important difference is that under this scenario the recession cohort effect would be predominantly driven by the type of firm at which the manager begins her career. So once we control for the characteristics of the firms where recession CEOs begin their careers, the general recession cohort effect would become much smaller. We call this the firm-specific channel. We show that 
this firm-specific effect explains an important fraction of the general cohort effect. One can think of this channel in the context of the model of Gibbons and Waldman (2006), which considers task-specific human capital. Their model builds on the classical matching model (Jovanovic 1979a) but adds a learning-on-the-job component. In this model, early job assignments can have a long-term career impact, since the first job affects the type of human capital a manager acquires (e.g., Jovanovic 1979b; Neal 1999; Gibbons and Waldman 2004). This channel is also consistent with a large literature in management science that points out the early-career stage as the relevant sensitive period of imprinting for individuals (e.g., Higgins 2005; McEvily, Jaffee, and Tortoriello 2012; Marquis and Tilcsik 2013). ${ }^{2}$

We begin by documenting that CEOs who started their career during a recession tend to have different career trajectories than those who started in economically prosperous periods. We refer to the former as recession CEOs. Recession CEOs tend to start in smaller or private firms. They on average hold fewer jobs and become CEOs more quickly, but ultimately end up heading smaller firms and receiving lower compensation (by about 20\%, in both cases) than their nonrecession peers. This lower pay for recession CEOs persists even after we control for firm size and performance. These outcomes are an indication that the careers of recession CEOs are

\footnotetext{
${ }^{2}$ Marquis and Tilcsik $(2013,199)$ define imprinting as "a process whereby, during a brief period of susceptibility, a focal entity develops characteristics that reflect prominent features of the environment, and these characteristics continue to persist despite significant environmental changes in subsequent periods.” A large literature, particularly in management science, has considered the imprinting of early career experiences on managers' long-run outcomes and strategies. See Marquis and Tilcsik (2013) for a recent review. However, the challenge in most of these papers is that the choices that managers make early in their careers might also reflect the individual's quality and characteristics. This endogeneity makes it difficult to interpret the causal direction of the effect, since long-run differences in a manager's career might not be influenced by a previously held job; it may be a function of the type of managers who select into such a job. By looking at recessions, we are able to identify an exogenous shock to managers' careers that does not suffer from this omitted variable bias. See Cornaggia and Zou (2008) and He et al. (2016) for a similar approach in the analyst and auditor setting, respectively.
} 
significantly affected by the economic environment when their careers begin. ${ }^{3}$ This lends support to the general recession effect, as described above.

The data suggest a particular channel through which recession CEOs are impacted: when we include the characteristics of the CEO's first job in the regression, we find that the coefficient on the recession dummy drops by approximately $20 \%$ to $50 \%$ (depending on the dependent variable for the CEO's career path being used). This is evidence for the firm-specific effect of recessions. For example, as discussed above, recession CEOs lead firms that are about 20\% smaller than those headed by non-recession CEOs. However, half of this effect is explained by the characteristics of the first job. These results suggest that one of the important channels through which recessions affect managerial careers is via distortions in the initial job allocation. Differences in initial job allocations during recession versus non-recession years appear to result in a different human capital mix or management style once a manager becomes CEO.

Second, we document that compared with non-recession peers within the same firm, recession CEOs have a more conservative management style. Recession CEOs display a tendency to invest less in capital expenditures (capex) and research and development (R\&D), and show lower overheads (i.e., selling, general, and administrative expenses). On the financing side, they have significantly lower leverage and working capital needs. They also display lower sales growth. However, they pay higher effective tax rates. In addition, recession CEOs have lower stock return volatility. We do not find evidence that recession CEOs have different rates of return on assets.

\footnotetext{
${ }^{3}$ In a similar spirit, several papers look at whether exogenous shocks to firm performance affect CEO compensation or CEO turnover. For example, Jenter and Kanaan (2015) find that CEOs are significantly more likely to be fired after a bad firm performance caused by factors beyond their control. See also Bertrand and Mullainathan (2001), Garvey and Milbourn (2006), Eisfeldt and Kuhnen (2013), and Jenter and Lewellen (2014).
} 
We note that the observed effects of recession CEOs on corporate policies are not the causal effects of randomly assigning a recession CEO to a firm. Management styles may be (at least partially) observable to the board before a new CEO is appointed. Therefore, firms with a need for a certain type of management style might opt for a CEO who has this style. ${ }^{4}$ As a result, the policy differences observed between recession and other CEOs are likely a combination of the true causal effects of recession CEOs and unobserved differences in (time-varying) firm characteristics. However, it is important to note that we do not find significant pre-trends in the year before the (recession) CEO is appointed. This result speaks to the fact that even if the board endogenously selects a CEO by management style, the CEO's presence is needed to implement the intended change. So indeed there appears to be something special about these CEOs' abilities. In sum, our findings imply that the pool of managerial talent in each cohort of new executives is significantly shaped by the overall economic conditions at the time of labor market entry.

In interpreting these results, we have to be careful to lay out the different channels through which economic conditions at career start might shape the composition of available managers (and managerial styles) in the economy. On the one hand are models of learning or imprinting, where early career experiences shape a manager's style. This could happen either through passive imprinting where the environment determines the skills that managers can learn (e.g., Baron, Burton, and Hannan 1999) or via a more active investment choice by managers as to which managerial style they want to develop (e.g., Gibbons and Waldman 2006; Dessein and Santos 2016). On the other hand, early economic environment could affect the selection of

\footnotetext{
${ }^{4}$ Fee, Hadlock, and Pierce (2013) argue for the importance of this channel.

${ }^{5}$ Yonker (forthcoming) points out geographic segmentation as another friction in the labor market for CEOs. A caveat of that study is that CEOs who grew up near the headquarters of large firms are in particular cities, predominantly large cities, and thus are subject to a host of different influences, opportunities, and selection issues.
} 
potential managers into this career. If people with different characteristics self-select or are hired for management positions during recessions versus non-recessions (for example, during a recession fewer or less talented people might start in management), our results might be partly driven by a selection channel. To analyze the importance of the selection versus imprinting channels, we test whether there are significant differences in the observable backgrounds of recession and non-recessions CEOs (e.g., their educational attainment or the quality of the schools they attended). We find no evidence of difference between them. Neither is there a significant difference between the average number of CEOs who started their careers in a recession year and the average number of CEOs who started in a normal year. Nevertheless, we cannot definitively rule out that selection might contribute to our estimated effect, since there could be differential selection on unobservable characteristics. However, independent of the specific channel, our findings suggest that the economic environment at the career start of managers can represent an important constraint on the type of executive talent that is ultimately available in the labor market.

Our work is related to a growing literature that looks at cohort effects in different labor markets. This research usually takes one of two approaches. The first approach requires having access to data on a specific population at the time it enters the labor market, as exemplified by Oyer (2006, 2008), Kahn (2010), Oreopoulos, von Wachter, and Heisz (2012), and Shu (2012, 2015). Perhaps most comparable to our work on the CEO labor market is Oyer (2008), who analyzes cohort effects for MBA graduates on their ability to obtain starting positions in the investment banking industry. Oyer shows that these initial job allocations affect the graduates' long-run success in the financial industry. Our work is complementary to these papers, since they predominantly focus on the extensive margin and show that employees or students who start in 
bad economic times get worse starting jobs and lower salaries or fail to get a job at all. We focus on the intensive margin and show that career progression and ultimate managerial style differ for recession CEOs versus non-recession CEOs.

The second approach is to condition on people who did become CEOs and analyze how the types of firms (or firm outcomes) vary with the CEO's background characteristics. The benefit of this approach is that researchers have access to a more representative set of CEOs. The disadvantage is that we do not observe the extensive margin (people who never become CEO). But as long as there is meaningful variation in the intensive margin (differences between the firms that CEOs run), which is the case among publicly listed U.S. firms, we can analyze the role CEO background plays in firm outcomes. A number of recent papers have used this approach, such as Malmendier and Tate (2008), Kaplan, Klebanov, and Sorensen (2012), Graham, Harvey, and Puri (2013), and Benmelech and Frydman (2015).

Finally, a few studies examine CEOs who grew up during or lived through the Great Depression. For example, Malmendier, Tate, and Yan (2011) investigate how the Great Depression experience affects corporate financial policies. ${ }^{6}$ Our paper differs in two important ways. First, we significantly expand the dimensions of corporate policies and the time period as well as include information about CEOs' full career history. Second and more importantly, we document that the impact of recessions works through the timing of a CEO's entrance into the labor market, rather than the timing of her upbringing. Since the sample in the earlier paper is relatively small due to historical data, the authors could not differentiate between birth cohort effects versus the impact of starting the career during a recession, as we suggest in our analysis.

\footnotetext{
${ }^{6}$ Malmendier, Tate, and Yan (2011) measure exposure to the Depression using a decade fixed effect for everyone born in the decade leading up to the Great Depression (i.e., 1920 to 1929) and compare them with those born in other decades. Malmendier and Nagel (2011) use a similar approach to show that past economic shocks have longlasting effects on individual investment choices, such as capital allocations to risky assets and stock market participation.
} 
By using the precise variation of the year when the CEO starts her first job, our results show that the important driver for a CEO’s managerial style and career path is whether the manager's entry into the labor market comes during a recession period, because it affects the manager's initial job allocation.

Graham and Narasimhan (2004) analyze whether CEOs who lived through the Great Depression had lower leverage levels going forward. Interestingly, the authors find that the leverage levels of Depression CEOs dropped in the aftermath of the crisis but that the use of debt increased during the 1940s at companies after the firm's Depression-era president retired or otherwise left the firm. The difference to our approach is that Graham and Narasimhan (2004) look at people who were already CEOs when the Depression hit, not managers who started their careers during the period. Their results therefore speak to the persistence and memory of shocks at the firm level, while we look at how management styles are formed at the individual manager level.

\section{Data Description and Sample Selection}

\subsection{Data construction}

Our data come from a number of different sources. We start with the companies and CEOs included in Compustat's Executive Compensation (Execucomp) database between 1992 and 2010. Execucomp covers the S\&P 1500 and companies that were once part of the S\&P 1500. For each of these CEOs, we collect their career history from different sources that contain biographical information about them. Those data sources include Biography in Context (formerly Biography Resource Center), ${ }^{7}$ Bloomberg, Forbes, and their companies’ own proxy filings. This

\footnotetext{
${ }^{7}$ Biography in Context combines biographies from printed Gale Group publications with biographies from The Complete Marquis Who's Who. The database also includes full-text articles from hundreds of periodicals.
} 
information allows us to compile data on the CEOs' career profiles and demographic characteristics. We collect information on the different companies and non-business entities that the managers worked for, the positions they held at each firm, and the dates those positions began and ended. In addition, we have information on the managers' birth year, birthplace, gender, marital status, political affiliation, religion, and educational background (the school where they earned their undergraduate degrees and any high-level degrees they may have obtained, such as an MBA, master's, or Ph.D., as well as the year they graduated). We also obtain information about whether CEOs were ever in the military or held political office or an academic position. This dataset is constructed at the CEO level so that we have one observation per person.

From these sources we find (some) background information for over 5,300 CEOs, which is about $80 \%$ of the CEOs in the Execucomp universe. In the first step, we focus on CEOs with relatively complete and continuous career profiles to examine how economic conditions at the beginning of an individual's career can impact her career path. For those CEOs, we have their complete career data from their first job, with no holes of more than three years at any point in their employment histories. Our sample includes 2,058 such CEOs.

\subsection{Descriptive statistics}

The descriptive statistics are tabulated in Table 1 . In our sample, $21 \%$ of the CEOs start their careers during a recession. Recession is a dummy variable that equals 1 if there is a recession in the calendar year when a CEO turns 24 years old, with recession years based on the business cycle dating database of the National Bureau of Economic Research (NBER). We code (calendar) years during which the economy is in a recession period (excluding the peak of a business cycle) as a recession year. To be classified as a recession year, the (calendar) year must 
either include the trough of a business cycle or fully fall into a recession period. These years receive a 1 while all remaining years, which are moderate to medium expansion years, are coded as 0 . We also repeat all our regressions using a measure of the depth of the recession instead of just a dummy for whether there is a recession when a manager's career begins. We measure a recession's depth as the number of months that it lasts, again based on the NBER recession dating convention. All the results are robust with this coding. ${ }^{8}$

The descriptive statistics in Table 1 show a large amount of mobility in the CEOs' career paths. It takes about 22 years for the average manager to achieve the CEO position, and the manager first becomes CEO at around 47 years old. ${ }^{9}$ By that time, the CEO has, on average, worked in two different industries and has been employed by three companies. The average manager has held about six positions before becoming CEO, with an average tenure for each prior job of three years. Note that these averages do not fully sum up to the average time to CEO of 22 years, since a number of CEOs hold appointments in non-business entities at some point in their careers, such as the government, a nonprofit, or an association. In the sample, $10 \%$ of the CEOs are firm founders; $15 \%$ have some prior banking or financial industry experience; $10 \%$ have some prior military experience; $8 \%$ started out as a consultant and $6 \%$ as a lawyer; $5 \%$ have held political office, while only $3 \%$ have spent time in academia; $18 \%$ started out in a private firm and $9 \%$ in a firm that ranks within the top ten firms, in terms of companies known for producing CEOs.

\footnotetext{
${ }^{8}$ A portion of the results from this alternative specification is tabulated in Table B5 in Appendix B. We also replicate the tests using unemployment rates as a measure of poor economic conditions. The results generally go in the same direction as the tests using recessions, but they are usually much noisier. Since unemployment rates are not as sharp a measure of poor economic conditions relative to recession dating, we prefer the specifications recorded here. In addition, general unemployment rates may not successfully capture labor market conditions for white-collar workers. The unemployment rates and our recession indicator based on NBER data have a correlation of $45 \%$.

${ }^{9}$ Out of these 2,058 CEOs, 149 were CEOs in several firms. For these multiple-firm CEOs, we focus on variables related to the first CEO position. We rerun all regressions using the variables related to the most recent CEO position or the CEO position with the largest firm size; our inferences are largely unchanged.
} 
We obtain data on sales for the first public firm at which the individual worked from Compustat (measured in the year the individual joined the firm). The average sales are $\$ 3,409$ million. We also obtain from Compustat data on sales, return on assets (ROA), and the Tobin's q of the firm where the manager becomes CEO, measured in the year immediately before the CEO starts the position. The average sales, ROA, and Tobin’s q are $\$ 3,117$ million, $15 \%$, and 1.76 , respectively. Finally, we obtain from Execucomp the first-year total compensation data for these CEOs. The distribution of the compensation variable is highly skewed (likely because of the very large first-year compensation packages for outside hires). The total value of the average (median) CEO’s compensation package including option grants is $\$ 3,299,000(\$ 1,678,000)$; the total value of the average (median) CEO’s compensation package including options exercised is $\$ 3,088,000$ $(\$ 1,206,000)$.

\subsection{Firm-level panel data}

We expand the sample in the second step to study how certain conditions at the beginning of a CEO's career ultimately affect her management style. In this step, we do not need detailed information on these individuals' career trajectories; we only require information on the year their careers begin, the year they become CEO, and the year they leave the position. Following Bertrand and Schoar (2003), we only include CEOs who were at that firm for at least three years to ensure that they were given a chance to make their mark on a given company. ${ }^{10}$ As is customary in management style studies, we exclude CEOs of financial, insurance, and real estate firms, as well as those of regulated utilities. These restrictions result in a sample of 4,152 CEOs.

We then form a dataset by merging these CEO characteristics and career profiles with Compustat firm-level data to obtain information about the type of firm a CEO heads. This results

\footnotetext{
${ }^{10}$ Our results are robust to removing this condition.
} 
in a panel dataset at the firm-year level for the period of the CEO's tenure, as well as at least the five years before the CEO took the job and the five years after leaving it, when such data are available. By construction, the dataset only contains CEOs who were at the helm of their companies in the years between 1992 and 2010. However, the firm-level panel data are not restricted to the 1992-2010 period if a CEO took office before 1992. Rather, the data include all available data points for a CEO’s tenure. ${ }^{11}$ For each firm-year, we know the characteristics of the relevant CEO. Firm-level data are not matched for any of the manager's periods of employment prior to becoming a CEO. Lastly, we obtain data on stock returns from the Center for Research in Security Prices (CRSP).

\subsection{Sampling strategy}

It is important to highlight the benefits and limitations of our sampling strategy. First, sample selection here is conditional upon managers who become CEOs at some point in their career and who were CEOs for some portion of the years between 1992 and 2010. While these CEOs are relatively successful managers in the first place, there is still a substantial amount of cross-sectional variation between firms, since public firms in the United States vary largely in their size, pay level, and other managerial success metrics. This heterogeneity gives us enough variation in CEO outcomes to differentiate between CEOs with tremendous successful careers and those who had more moderate outcomes.

An alternative sampling strategy would be to look at the unconditional probabilities of selecting into the CEO position. For this purpose, we would need to get data on an entire cohort

\footnotetext{
${ }^{11}$ When using the pre-1992 observations, we effectively compare the policies of a recession CEO who remained in the position until at least 1992 to the policies of a succeeding non-recession CEO (within the same firm) who became CEO after 1992 or the policies of a non-recession CEO who remained in the position until at least 1992 to the policies of a succeeding recession CEO (within the same firm) who became CEO after 1992. Hence, including the pre-1992 observations gives us a better measure of the average style of a CEO who started office before 1992. Nevertheless, to ensure that this sampling strategy does not induce a bias, we perform a robustness check by dropping all the pre-1992 observations and using the 1992-2010 sample. Our inferences are largely unchanged.
} 
of managers that start in a given year and follow their career paths over time. The advantage of this sample is that we could observe if there are systematic factors that predict whether or not a given manager will become a CEO. However, the main difficulty with this alternative sampling strategy is how to determine the population at risk. For example, one could focus on the cohort of MBAs that graduate each year in the United States. But such data are obviously very difficult to collect. ${ }^{12}$ In addition, more than one-half of the CEOs in our sample do not have MBAs. So ideally one would have to cast an even wider net.

One potential issue with our sampling strategy is that managers who began their careers during recessions may be less likely to become CEOs in the first place. However, we believe that this is not a first-order concern in our data, because if it were, our sample would have fewer future CEOs starting in a recession year than those starting in a non-recession year. This is not the case: in our sample, the average number of CEOs who started their careers in a recession year is not statistically different from the average number of CEOs who started in a normal year. As an additional test, we focus on the sample of executives in the Execucomp database between 1992 and 2010 and test whether recession starters are less likely to become CEOs than their nonrecession peers. Specifically, we take each (birth) cohort of executives and calculate the fraction of managers that become CEOs. We regress this variable on a dummy for whether there is a recession when each cohort enters the job market. The coefficient on the recession dummy is not statistically different from zero, suggesting that there is no difference in the supply of CEOs during a recession versus a non-recession.

A related issue with our sampling strategy is that there may be differential selection into the CEO labor market during recessions versus non-recessions. To test this, we create a dummy for whether a manager obtains her undergraduate or postgraduate degree from an Ivy League

\footnotetext{
${ }^{12}$ Kuhnen (2011) is a recent paper that examines one cohort of MBAs.
} 
school, ${ }^{13}$ and we regress this variable on a dummy for whether the manager enters the labor market during a recession. The coefficient on the recession dummy is very close to zero, but the standard error is very large. Similarly, we do not find significant differences in the number of degrees (such as MBA, master's, or Ph.D.) between recession and non-recession CEOs. Therefore, it appears that the pool of candidates who enter the CEO labor market does not change significantly over the business cycle (based on their observable characteristics). However, we acknowledge that there could be differential selection on unobservable characteristics, which can partly contribute to our results.

An additional selection issue concerns the coverage of managers in sources like Biography in Context, Bloomberg, and Forbes. Managers of larger and more successful firms might be more likely to be included in such biographical sources. Moreover, these CEOs might also be more willing to share information with the public. To avoid systematic bias in the completeness of information due to selective disclosure from voluntary sources, we supplement the data collection with biographical information from proxy filings. Even after using a combination of these sources, there is indeed more systematic coverage of the CEOs of larger firms, but there is no bias in the types of CEOs covered in later versus earlier years. It is reassuring that the composition of firms and managers who are covered over time does not show much change. Since the tests in this paper rely on longitudinal variation across managers from different cohorts, if the type of firms covered changes over time, our results could be affected. To further alleviate this potential concern, we include decade fixed effects in all regressions.

Finally, the sampling strategy employed here is more likely to include CEOs in the later part of the sample if their ascent to CEO was very rapid. Managers who take a longer time to

\footnotetext{
${ }^{13}$ Results are quite similar when we define the dummy variable based on the top ten (or twenty) schools instead of Ivy League schools.
} 
become CEO will be dropped from the sample since their slower trajectory means that they will not have become CEO by the time the data are selected. To control for this bias, we rerun all regressions for only those CEOs with a fast trajectory (e.g., the top $50 \%$ of the sample, in the sample's early and later years). This lets us compare fast-track managers across different time periods. However, there is a concern that these CEOs are fundamentally different from the rest of the market. In response to this concern, we conduct a second robustness check that follows all the CEOs in one cohort. We only include CEOs who started their careers before 1980, and we repeat the analysis for different time cutoffs. The latter approach allows us to look at all CEOs within the older cohorts. With either approach, our inferences on CEOs' early career paths are largely unchanged.

\section{CEO Careers and Early Recessions}

\subsection{Early recessions}

In the first step, we want to understand how the economic conditions in place when a manager enters the labor market affect her type of career. The motivation behind this analysis is that early career experiences may have a long-lasting imprint on the manager's career outcomes. In the second step, we analyze whether these early career experiences also affect the CEO's management style.

There is a widespread perception that early career experiences can shape a manager and might have lasting career effects. The challenge in testing the validity of these arguments is that choices made early in a manager's professional arc are not exogenous, but depend on the person's skill, preferences, and other unobservable characteristics. For example, obviously, better employers are able to attract the best candidates at every level, even if they do not have a causal impact on these employees' careers. 
One factor that is exogenous to managers' career choices is the economic conditions when managers enter the labor market, since a person's birth date is largely exogenous to her life. However, if smart individuals are aware that it is disadvantageous to embark on a career in a downturn, they might try to postpone their entrance into the labor market during a recession. In that case, the most well-informed and potentially smartest people would delay entering the market, while the average employee would not, a phenomenon that would then lead to selection effects. To avoid this type of selection bias, we proxy for the exogenous starting date by using a person's birth year plus 24. This specification is based on the observation that the distribution of starting ages has a strong mode at 24 , as shown in Table 2 . The likelihood of someone starting her first full-time job at the age of 24 is more than $21 \%$ and is almost double the likelihood of starting work at age 23 . The likelihood of starting at age 25 is $16 \%$, but then quickly drops with age. Therefore, we use 24 as the target age at which managers enter the labor market. ${ }^{14}$

This empirical strategy allows us to focus solely on the exogenous portion of managers' starting conditions and not the endogenous choices they might make in timing when to begin their careers. Our main variable of interest, Recession, is a dummy variable that equals 1 if there was a recession at the time of the manager's job market entry, and 0 otherwise. We refer to managers who started their careers during a recession as recession CEOs. ${ }^{15}$

\footnotetext{
${ }^{14}$ Our results are robust when we define Recession as a dummy variable that equals one if there was a recession during the calendar year when a CEO reached the age of 24 or 25.

${ }^{15}$ In untabulated results, we see that recession CEOs tend to enter the labor force when they are older (marginally significant), compared with non-recession CEOs. This result suggests that some individuals do delay entering the job market during a recession, which could be evidence of endogenous entry into the labor market. However, we find no evidence that those recession CEOs who delayed their job market entry have different outcomes from other recession CEOs.
} 


\subsection{Early career path}

In Table 3, we analyze a manager's career path as a function of the economic conditions at the time of labor market entry. ${ }^{16}$ We regress different measures of the shape of the career path on a dummy for whether there was a recession at the time the manager entered the job market (proxied by birth year plus 24). ${ }^{17}$ The specification controls for decade fixed effects (for the decade in which a manager was born) to account for any long-run trends in the economic environment and in the way CEO careers have evolved in the United States. ${ }^{18}$ Therefore, the variation in these regressions comes from comparing CEOs who started during a recession year with CEOs who started during a non-recession year in the same decade. We also control for the industry in which a CEO started her career, where industry effects are measured at the one-digit SIC level. ${ }^{19}$ The rationale for including industry controls is that different industries might vary in their propensity for and speed of promotion. It would be especially interesting if, in a recession year, there are large differences in the types of industries where future CEOs begin their careers. However, our results show that the coefficient of interest on the recession dummy is almost unchanged when we do not include the industry fixed effect. These results suggest that selection into industries based on the economic conditions when the CEO enters the job market does not have a measurable effect on her career path.

\footnotetext{
${ }^{16}$ The univariate statistics on the overall differences between recession and non-recession CEOs are consistent with the results reported in Tables 3 and 4 (see Table B1 in Appendix B). The univariate statistics on the overall differences between recession CEOs and non-recession CEOs who are matched based on their being very close in age to recession CEOs yield similar inferences.

${ }^{17}$ Throughout the paper, we compare recession CEOs with non-recession CEOs. In additional analysis, we include in the regressions a boom dummy, an indicator variable for CEOs who entered the labor market in business cycle peaks, according to the NBER's business cycle dating database. We use those CEOs who started their careers in neither recessions nor booms as the benchmark group. We continue to find quite similar results for recession CEOs. However, we do not find any significant effects for boom CEOs on any of our outcome variables. The coefficients on the boom dummy in all the regressions are very close to zero and the standard errors are very large.

${ }^{18}$ A general perception of the executive labor market is that CEOs' careers have become more active with a quicker rise to the top position and more movement across firms and industries (e.g., Parrino 1997; Murphy and Zabonjik 2007; Bertrand 2009; Frydman and Saks 2010; Frydman forthcoming). Our results are robust to including a linear time trend in addition to the decade fixed effects.

${ }^{19}$ We code consulting and law firms as separate industries.
} 
Columns 1 and 2 of Panel A show that, on average, recession CEOs are promoted into the top job about 1.5 years faster $(p=0.005)$ and that they are about one year younger $(p=0.044)$. We then look at the number of industries and firms in which a manager was employed in the course of her career prior to becoming CEO. Columns 3 and 4 show that recession CEOs have less mobility across both industries and firms: the effects are not very large and the coefficients are $-0.128(p=0.013)$ and $-0.137(p=0.094)$, respectively. In column 5 , we look at the number of business positions a person has held before first becoming CEO. CEOs who started during recession periods hold fewer positions before becoming CEO compared with individuals who started in other years. The coefficient is $-0.421(p=0.049)$, which translates, for an average manager, to about one less year before becoming CEO $(-0.421 \times 2$, the median of average tenure as shown in Table 1). Column 6 shows that for people who started in recession years, their average tenure in a position is longer. The dependent variable $A v$ Tenure is calculated as the number of years a manager remained in a given position, averaged over all positions held over the course of that manager's career prior to becoming CEO. The coefficient of 0.367 ( $p=0.057)$ translates, for an average manager, to about two more years prior to becoming CEOs. Finally, in column 7, we do not find evidence that the economic conditions when a manager's career begins affect the probability of her being the founder of the firm..$^{20}$

In Panel B of Table 3, we document that managers who started their careers during recessions have different early career experiences. The regressions in columns 1 to 8 are linear probability models. ${ }^{21}$ Recession CEOs are less likely to start out as consultants (coef. $=-2.5 \%$ and $p=0.071$ in column 3), more likely to work in private firms when entering the labor force

\footnotetext{
${ }^{20}$ In our sample, 320 individuals spend their entire careers at one firm (i.e., they start at an S\&P 1500 firm and ultimately become the CEO of that firm). We find that recession CEOs are more likely to have one-firm professional arcs. Our inferences are unchanged after we drop these individuals.

${ }^{21}$ Results are similar with logit regressions.
} 
(coef. $=4.3 \%$ and $p=0.057$ in column 7), and less likely to get their first jobs in a top-ten firm that is known for producing CEOs (coef. $=-3.1 \%$ and $p=0.022$ in column 8). In addition, when we look at the sales of the first public firms where these individuals worked, we find that recession CEOs tend to work in smaller firms compared with non-recession CEOs (column 9). ${ }^{22}$ The coefficient of $-0.29(p=0.019)$ suggests that, on average, the first public firm's sales are $25 \%\left(\mathrm{e}^{-0.29}-1\right)$ lower for recession CEOs than they are for non-recession CEOs. This result is not driven by small firms hiring more during recessions. In fact, we find evidence of the opposite: small firms hire less during recessions (untabulated), consistent with Davis, Haltiwanger, and Schuh (1996). We do not find evidence that beginning a career during a recession affects the chances of being hired by a bank (column 1), the military (column 2), a law firm (column 4), the government (column 5), or academia (column 6).

\subsection{Career outcomes}

We next examine whether starting during a recession also affects a manager's ultimate career outcome. In Table 4, we focus on two measures that can proxy for career outcome: the size of the firm where the manager becomes CEO, and her total compensation for her first year as CEO. We measure firm size as the natural logarithm of sales in the year before the CEO starts the position. We also look at the ROA and Tobin's q of the firm where the manager becomes CEO. ${ }^{23}$

Column 1 of Table 4 suggests that on average, recession CEOs ultimately head smaller firms relative to managers who started in non-recessions; the coefficient of -0.234 ( $p=0.037)$ suggests that on average, the firm size for recession CEOs is $20 \%\left(\mathrm{e}^{-0.234}-1\right)$ smaller than it is

\footnotetext{
${ }^{22}$ We also find that in the subsample of individuals who started their careers in a public firm (749 observations with sales data), recession CEOs tend to work at smaller firms than do non-recession CEOs.

${ }^{23}$ The decline in sample size from Table 3 to Table 4 is due to the fact that we do not observe those firm characteristics if a manager first becomes the CEO of a private firm.
} 
for non-recession CEOs. However, we find no discernible difference in terms of profitability (column 2) or valuation (column 3), suggesting that these firms are not necessarily of a worse type. In columns 4 and 5, we look at two proxies for these individuals' total compensation for their first year as CEOs: total compensation including option grants and total compensation including options exercised. ${ }^{24}$ The coefficient on Recession is negative in both columns, though it is only significant in column 5 . The coefficient of $-0.174(p=0.048)$ in column 5 suggests that on average, recession CEOs receive 16\% $\left(\mathrm{e}^{-0.174}-1\right)$ lower compensation than do non-recession CEOs. In addition, this lower pay is not just a function of running a smaller firm, since it persists even after we control for firm size and profitability. The coefficient of $-0.112(p=0.086)$ in column 7 suggests that on average, the negative effect of recession on pay is $-11 \%\left(\mathrm{e}^{-0.112}-1\right)$, holding firm size and profitability constant. ${ }^{25}$ In untabulated tests, we decompose the total compensation and find that recession CEOs receive considerably less non-option compensation (salary and bonus), but we do not find a systematic pattern on either options granted (using Black-Scholes) or value realized on option exercise.

Overall, these results suggest that managers who started in recession years on average hold fewer positions and reach CEO more quickly. Moreover, these early career experiences have a lasting impact on the ultimate outcome of a manager's career, since such managers head smaller firms and receive less total compensation when they become CEOs. ${ }^{26}$

\footnotetext{
${ }^{24}$ The distribution of the compensation variable is highly skewed. In the regressions, we use log-transformed values and winsorize the variables at the top and bottom $1 \%$ to mitigate the influence of extreme values. Our inferences are unchanged when we winsorize the variables at the top and bottom $5 \%$ or when we run median regressions.

${ }^{25}$ Results are robust to controlling for the age of the CEO. In addition, when we supplement the data with the first available data from Compustat (to achieve the full sample of 2,058 observations) and rerun all the regressions in Table 4, we obtain quite similar results.

${ }^{26}$ We do not find evidence that recession CEOs are more likely to move onto a second CEO position. This result allows us to rule out the possibility that these CEOs become CEO at a larger, higher-paying firm following their first CEO position.
} 


\subsection{The first job's impact}

If embarking on a career during a recession affects a manager's initial job assignment while also shaping her ultimate career outcome, it raises the question of whether recessions have an independent effect on both of these dimensions or whether the recession's impact affects career outcomes mainly by distorting the initial job allocation. To test this hypothesis, we rerun our regressions in Tables 3 and 4 but include controls for the characteristics of the manager's first job. ${ }^{27}$ If recessions affect managers’ careers mainly by assigning them to more non-standard jobs, the coefficient on the recession dummy should drop in size when we control for job characteristics. We focus on two major characteristics we established in Panel B of Table 3: size of firm (first sales) and a dummy for whether the firm is private. ${ }^{28}$

In Panel A of Table 5, we find that after controlling for these job characteristics, the estimated coefficients on the recession dummy are much smaller across most dimensions. In column 1, the dependent variable is the time it takes a manager to become CEO (time to CEO). The coefficient on recession is $1.19(p=0.024)$ when the first job characteristics are included, but it is almost $1.55(p=0.005)$ in Table 3. Similarly, in column 2 we repeat the same regression but use Age to $C E O$ as the dependent variable. Again the estimated coefficient on the recession dummy drops by $18 \%$. These effects are even bigger for the number of positions and industries CEOs pass through in the course of their careers; see columns 3 through 5. Here, the inclusion of job characteristics reduces the size of the recession dummy by at least $25 \%$.

\footnotetext{
${ }^{27}$ Though it is clearly more endogenous, we also examine the correlation between early career choice and career progression to CEO. For example, we find that starting in a firm that ranks within the top ten firms, in terms of companies known for producing CEOs, is associated with becoming CEO of a larger company and receiving higher compensation. These results are interesting but cannot be interpreted in a causal way because people with different qualifications and of different types might choose these differing career paths early on.

${ }^{28}$ We do not control for Top ten because it is strongly correlated with firm size, which is included in the regression. Nevertheless, the results are quite similar when we add Top ten as an additional control.
} 
In Panel B of Table 5, we now repeat a parallel exercise by looking at career outcomes. In column 1, we look at the size of the firm at which a manager becomes CEO. Including the characteristics of the first job reduces the size of the estimated coefficient on the recession dummy by almost $50 \%$, and the coefficient becomes statistically insignificant. In column 5 , the effect of recession on the total compensation as CEO is also reduced by $17 \%$ after controlling for first job characteristics. However, in column 7, the coefficient on the recession dummy remains almost unchanged when we control for the starting position. This result might be driven by the fact that the additional control variables (Size, Sales, $R O A$ ) already reflect, to a certain extent, the initial job characteristics, as these variables are also likely to be affected by the starting job.

Together, the results in Table 5 suggest that a significant part of the recession effect is due to the characteristics of the firms in which they start-that is, the firm-specific channel: managers who started their careers in smaller or private firms rise to the top position more quickly and at a younger age, and they eventually become CEOs at smaller firms and earn less compensation.

Finally, we explore whether there is an interaction effect between the firm-specific channel and the recession cohort effect-that is, whether the differences in the firm-specific effects previously discussed become stronger during a recession. This interaction effect might be the result of either a change in the types of managers who started in small firms during recessions or a differential learning effect. For that purpose, we interact Recession with the initial job characteristics (i.e., First sales or First private) and include these two interaction terms in all regressions of Table 5. In untabulated tests, we find that the interaction effect is significant for a subset of dependent variables such as Time to CEO, Age to CEO, and Num firms. The coefficients on the interaction terms are not statistically significant for other outcome variables. 


\subsection{Robustness checks}

When examining the effect of recessions on CEO careers (Tables 3 and 4), we use a sample of 2,058 CEOs for which we are able to collect complete career data. However, as we mentioned earlier, we are able to find some background information for over 5,300 CEOs. The concern is that the sample attrition might be linked to CEOs' career choices and differ between recession and non-recession CEOs. For example, if more recession CEOs have circuitous career paths with unusual interludes that they later downplay, then these CEOs might be more likely to be dropped from the sample. Hence, the finding that recession CEOs, on average, hold fewer jobs and become CEOs more quickly might be due to the fact that recession CEOs who had circuitous career paths have been dropped.

To address this concern, we repeat the analysis in Tables 3 and 4 with a larger sample. Many of the career path and career outcome variables analyzed in Tables 3 and 4 do not actually require information on the complete career path. All that is required to analyze Time to CEO, Age to CEO, and all the variables in Table 4 is information on the CEO's age, when they first become CEO, and the firm at which they do so. This information is available for almost the entire sample. Our inferences are unchanged when the analysis is repeated for this larger sample of over 5,300 CEOs (see Tables B2 and B3 in Appendix B).

Interestingly, by comparing the summary statistics between the restricted, fullinformation sample and the larger sample, we find that the dropped CEOs have a longer Time to CEO (3.6 years) and a higher Age to CEO (2.3 years), both of which are statistically significant at the $1 \%$ level. However, this selection does not seem to induce a bias because it is not the case that recession CEOs are more likely to be dropped. In addition, the differences between dropped 
recession CEOs and dropped non-recession CEOs are consistent with our findings for the restricted sample.

Another potential concern is that our results might be driven by one or two recessions in the early 1970 s or 1980 s in combination with the technology boom of the late 1990 s and/or the financial crisis of the late 2000s. For example, recessions occurred in 1970 and 1973-75, and many CEOs who started their careers during these recessions probably became CEOs during the late 1990s. Hence, the finding that these CEOs became CEOs earlier in their careers, at a younger age, and at firms with smaller sales might have nothing to do with the 1970s-era recessions, and a great deal to do with the 1990s technology boom. Put differently, if an unusually large number of recession CEOs started (or were in office) during unusual periods, such as the technology boom or the financial crisis, then recession CEOs might appear different for reasons that have nothing to do with the economic conditions at the start of their careers. To ensure that the results on CEO career paths (Table 3, Panel A) and on the first firm where a manager becomes CEO (Table 4) are not driven by either the technology boom or the financial crisis, we perform a robustness check by dropping CEOs who started in 1996-2000 or 20082009. Our results are robust to dropping these CEOs (untabulated).

A related concern is that the recessions that dominate the results may be correlated with various wars in which young men were drafted. To alleviate this concern, we control for a CEO’s military experience. Our results continue to hold (untabulated).

\section{Managerial Styles and Early Recessions}

The second major question of the paper is the impact early career experiences can have on the management style a manager adopts even decades later as CEO. On average, this time lag would be twenty years after these CEOs started their first jobs. Do managers who started their 
careers during recessions have a more conservative management style than those who started in non-recessions? This test is similar to the approach used by Bertrand and Schoar (2003), who use changes in observable outcomes at the firm level as an indicator of the impact that the CEO has on the firm. However, we do not have to rely solely on firm switchers (i.e., CEOs observed in multiple firms) since we can examine changes in firm behavior when a recession CEO replaces a non-recession CEO or vice versa.

To test this hypothesis, we start with Compustat data for the years that a given CEO was at the firm's helm. We then match the CEO’s career history to the annual firm data for her tenure as CEO of that company. The firm-level variables of interest are corporate outcomes related to investment, financial, and tax policies, as well as organizational strategy, firm risk, and operating performance. We regress firm outcomes on the CEO’s career profile to test whether decisions vary systematically based on the CEO's profile. To account for fixed differences in outcomes at the firm level, in all regressions we control for firm fixed effects. Thus, the Recession coefficient is identified from firms switching from a recession CEO to a non-recession CEO, or vice versa. ${ }^{29}$ As before, we also include decade fixed effects (based on the decade in which the CEO was born) to control for any long-run trends in management styles and economic conditions. The variation in these regressions comes from differences in firm outcomes between CEOs who started during recessions and those who started in non-recessions within a given decade. ${ }^{30}$ To remove time-varying changes in macro or industry conditions, we control for (two-digit SIC) industry-year fixed effects. ${ }^{31}$ We report robust standard errors clustered at the firm level.

\footnotetext{
${ }^{29}$ We find that the probability of hiring a recession (versus non-recession) CEO is not affected by the incumbent CEO's type, suggesting that firms do not proactively select into a certain type of CEOs.

${ }^{30}$ Decade fixed effects subsume the "Depression Baby" effect documented in Malmendier, Tate, and Yan (2011). In untabulated tests, we include a continuous control for CEO age and find quite similar results.

${ }^{31}$ Industry-year fixed effects do not subsume decade fixed effects because industry-year fixed effects are based on the years that the CEO heads the company, while decade fixed effects are based on the decade in which the CEO was born.
} 
The results from these tests are presented in Table 6. We include basic control variables in these regressions, mainly following Bertrand and Schoar (2003). ${ }^{32}$ In columns 1 and 2, we report the results for investment policy. The first variable in the table is capital expenditures. The specification includes controls for cash flows, lagged Tobin's q, and sales growth. Managers who started during a recession tend to have lower levels of capital expenditures than managers who started in non-recession periods; the effect is $-0.4 \%$ of lagged total assets $(p=0.012)$. The next variable is $R \& D$ expenditures. The result shows that recession CEOs also spend less on $R \& D$, and the effect is $-0.4 \%$ of lagged total assets $(p=0.003$ ). The first two columns suggest that recession CEOs have more conservative investment policies than their non-recession peers.

Column 3 shows that recession CEOs have lower selling, general, and administrative expenses (coef. $=-1.2 \%$ and $p=0.040$ ). Columns 4 and 5 focus on financial policy. Column 4 shows that leverage levels are significantly lower for firms led by recession CEOs (coef. $=0.8 \%$ and $p=0.040$ ). This result on leverage is robust to including the full set of controls, as in Table VII of Malmendier, Tate, and Yan (2011). Column 5 shows that recession CEOs also have lower working capital needs (coef. $=-1.8 \%$ and $p=0.008$ ). In addition, column 6 shows that recession CEOs display lower sales growth (coef. $=-1.6 \%$ and $p=0.009$ ).

In column 7, we look at the tax policy. Basic control variables include firm size, a dummy for whether the firm has a positive value of tax loss carry-forward (TLCF), and sales growth. Dyreng, Hanlon, and Maydew (2010) document that individual executives play a significant role in determining the level of tax avoidance that firms undertake. We find that firms led by recession CEOs have higher effective tax rates as measured by the ratio of cash taxes paid to pre-tax income (coef. $=1.7 \%$ and $p=0.002$ ).

\footnotetext{
${ }^{32}$ In untabulated tests, we also construct a variable that measures the number of recessions in a CEO's career and use it as a competing explanatory variable. The magnitudes and statistical significance of the coefficients on Recession remain quite similar to those reported.
} 
In column 8, we look at the overall riskiness of firms as proxied by stock return volatility (Coles, Daniel, and Naveen 2006). The result suggests that recession CEOs have lower stock return volatility (coef. $=-4 \%$ and $p<0.001$ ). Finally, we look at the effect of recession CEOs on firms’ operating performance. Column 9 shows that a recession CEO’s firm has a similar rate of return on assets (ROA) as the firm of a non-recession CEO (coef. $=-0.2 \%$ and $p=0.511$ ). In column 10, we use an alternative accounting measure of performance that is less subject to accounting manipulations, operating cash flow (as a ratio of lagged total assets); we find a quite similar result (coef. $=-0.2 \%$ and $p=0.417){ }^{33}$

We check the robustness of these results with bootstrapping. Specifically, we create a pseudo recession CEO indicator, where the probability of drawing a 1 is $18.8 \%$ (i.e., the actual percentage of recession CEOs in the sample) and the probability of drawing a 0 is $81.2 \%$, and then run the same regressions of Table 6 with this pseudo recession CEO indicator (as opposed to the actual recession CEO dummy). We repeat this exercise 1,000 times. Panel A of Table 7 reports the distribution of $t$-statistics on the pseudo recession CEO indicator based on 1,000 simulations. Panel B of Table 7 reports the actual $t$-statistics (based on the actual recession CEO dummy) and the associated $p$-values inferred from the empirical distributions reported in Panel A. For example, the actual $t$-statistic on the recession CEO dummy when the dependent variable is capital investment is -2.53 . Out of the 1,000 simulations, five generate $t$-statistics that are lower than this number, and seven generate $t$-statistics whose absolute value exceeds 2.53 . Thus,

\footnotetext{
${ }^{33}$ We also look at several additional corporate policy variables and generally do not find that recession CEOs have a significant impact on them (e.g., total number of acquisitions, interest coverage, dividends, total number of business segments, profit margin, accounting conservatism, long-term assets, and asset turnover). An interesting result is that recession CEOs have lower cash holdings. Based on the precautionary motive behind cash holdings (Bates, Kahle, and Stulz 2009), this result suggests that recession CEOs are less conservative. However, the tax-based explanation of cash holdings suggests that firms hold cash in their foreign subsidiaries because of the tax costs associated with repatriating foreign income (Foley et al. 2007). Thus, the result that recession CEOs hold less cash is consistent with our finding that recession CEOs engage in less aggressive tax avoidance. Disentangling these two explanations is beyond the scope of this paper.
} 
the one-sided $p$-value is 0.005 and the two-sided $p$-value is 0.007 . These results show that with the pseudo recession CEO indicator, we do not get the same results as in Table 6 and that the $p$ values based on clustered standard errors in Table 6 are similar to those inferred based on bootstrapping.

Taken together, the results seem to suggest that recession CEOs indeed manage their firms more conservatively. In untabulated results, we see that recession CEOs and non-recession CEOs have the same length of CEO tenure, so any results that we find on the differences in CEO style are not driven by their horizon with their firm. In a further analysis, we ask whether recession CEOs manage firms differently during recessions or non-recessions. It is possible that recession CEOs manage firms more efficiently during recessions and perform better in such difficult periods, while non-recession CEOs are better at managing firms in non-recessions. However, our results indicate that recession CEOs do not perform differently during recessions or non-recessions. ${ }^{34}$ This result supports the notion that managerial styles, once formed, are relatively fixed over time.

\section{Conclusion}

The results of this paper suggest that the economic environment at the start of a manager's career has a lasting impact on her career path and managerial style. Early career conditions affect the manager's career path toward CEO and her career outcomes, as measured by the size of firm she manages and the level of compensation. The data suggest that a major channel that produces differences between recession and non-recession CEOs involves their first

\footnotetext{
${ }^{34}$ Specifically, we create a dummy for whether the firm-year is a recession year (based on the NBER business cycle dating database) and interact it with our original recession CEO dummy. We rerun all regressions in Table 6 with the recession year dummy, the recession CEO dummy, and the interaction term of these two. The coefficients on the recession CEO dummy remain similar to those reported in Table 6, but we do not find any significant coefficient for the interaction term. Results are similar when we define a recession year as one when the industry stock return is below the market stock return.
} 
job: recession CEOs start at smaller or privately held firms rather than large, public firms. We also observe that beginning one's career during a recession leads to a more conservative management style, such as lower leverage and more cost cutting.

These findings can have broad implications for the managerial labor market. Whether recessions affect the formation of CEOs via imprinting or selection, we find that these cohort effects seem to change the composition of available management styles at a future point in time. For instance, after extended periods of high growth, a large number of managers may have learned how to manage growing companies, but there could be a limited supply of managers who know how to run firms in distress or in turnaround situations. While the CEO labor market might efficiently allocate managers to firms with the highest need for a specific style at a given point in time, the persistence of these managerial styles might have long-run effects on the optimal skill mix in the economy. For example, Schoar and Zuo (2016) show that the announcement returns around the appointment of a recession CEO are significant and positive. If markets on average are rational in predicting the type of CEO a firm might select, the good news around the selection of recession CEOs suggests that there is a limited supply of these types of CEOs in the market. Of course, more research is needed to better understand the functioning of the executive labor market and its impact on the formation and composition of managerial styles in this market. 


\section{References}

Bates, T. W., K. M. Kahle, and R. M. Stulz. 2009. Why do U.S. firms hold so much more cash than they used to? Journal of Finance 64:1985-2021.

Baron, J., D. Burton, and M. Hannan. 1999. Engineering bureaucracy: The genesis of formal policies, positions, and structures in high-technology firms. Journal of Law, Economics, and Organization 15:1-41.

Benmelech, E., and C. Frydman. 2015. Military CEOs. Journal of Financial Economics 117:4359.

Bennedsen, M., K. M. Nielsen, F. Pérez-González, and D. Wolfenzon. 2007. Inside the family firm: The role of families in succession decisions and performance. Quarterly Journal of Economics 122:647-91.

Bertrand, M. 2009. CEOs. Annual Review of Economics 1:121-50.

Bertrand, M., and S. Mullainathan. 2001. Are CEOs rewarded for luck? The ones without principals are. Quarterly Journal of Economics 116:901-32.

Bertrand, M., and A. Schoar. 2003. Managing with style: The Effect of Managers on Firm Policies. Quarterly Journal of Economics 118:1169-1208.

Coles, J. L., N. D. Daniel, and L. Naveen. 2006. Managerial incentives and risk-taking. Journal of Financial Economics 79:431-68.

Cornaggia, J., and L. Zou. 2008. Does initial placement matter for equity analysts' forecast accuracy? Working Paper.

Davis, S. J., J. C. Haltiwanger, and S. Schuh. 1996. Job creation and destruction. Cambridge, MA: MIT Press.

Dessein, W., and T. Santos. 2016. Managerial style and attention. Working Paper.

Dyreng, S. D., M. Hanlon, and E. L. Maydew. 2010. The effects of executives on corporate tax avoidance. Accounting Review 85:1163-89.

Eisfeldt, A. L., and C. M. Kuhnen. 2013. CEO turnover in a competitive assignment framework. Journal of Financial Economics 109:351-72.

Fee, C. E., C. J. Hadlock, and J. R. Pierce. 2013. Managers with and without style: Evidence using exogenous variation. Review of Financial Studies 26:567-601.

Fligstein, N. 1990. The transformation of corporate control. Cambridge, MA: Harvard University Press.

Foley, C. F., J. C. Hartzell, S. Titman, and G. Twite. 2007. Why do firms hold so much cash? A tax-based explanation. Journal of Financial Economics 86:579-607.

Frydman, C. Forthcoming. Rising Through the Ranks: The Evolution of the Market for Corporate Executives, 1936-2003. Management Science.

Frydman, C., and R. Saks. 2010. Executive compensation: A new view from a long-term perspective, 1936-2005. Review of Financial Studies 23:2099-2138. 
Garvey, G. T., and T. T. Milbourn. 2006. Asymmetric benchmarking in compensation: Executives are rewarded for good luck but not penalized for bad. Journal of Financial Economics 82:197-225.

Gibbons, R., and M. Waldman. 2004. Task-specific human capital. American Economic Review 94:203-7.

- 2006. Enriching a theory of wage and promotion dynamics inside firms. Journal of Labor Economics 24:59-107.

Graham, J. R., C. R. Harvey, and M. Puri. 2013. Managerial attitudes and corporate actions. Journal of Financial Economics 109:103-21.

Graham, J. R., and K. Narasimhan. 2004. Corporate survival and managerial experiences during the Great Depression. Working Paper.

Hambrick, D. C., and P. A. Mason. 1984. Upper echelons: The organization as a reflection of its top managers. Academy of Management Review 9:193-206.

He, X., S. P. Kothari, T. Xiao, and L. Zuo. 2016. Long-term impact of economic conditions on auditors' judgment. Working Paper.

Higgins, M. C. 2005. Career imprints: Creating leaders across an industry. San Francisco, CA: Jossey-Bass.

Jenter, D., and F. Kanaan. 2015. CEO turnover and relative performance evaluation. Journal of Finance 70:2155-84.

Jenter, D. and K. Lewellen. 2014. Performance-induced CEO turnover. Working Paper.

Jovanovic, B. 1979a. Job matching and the theory of turnover. Journal of Political Economy 87:972-90.

— 1979b. Firm specific capital and turnover. Journal of Political Economy 87:1246-60.

Kahn, L. B. 2010. The long-term labor market consequences of graduating from college in a bad economy. Labour Economics 17:303-16.

Kaplan, S. N., M. M. Klebanov, and M. Sorensen. 2012. Which CEO characteristics and abilities matter? Journal of Finance 67:973-1007.

Khurana, R. 2002. Searching for a corporate savior: The irrational quest for charismatic CEOs, Princeton, NJ: Princeton University Press.

Kotter, J. P. 1982. The general managers. New York: Free Press.

Kuhnen, C. M. 2011. Searching for jobs: Evidence from MBA graduates. Working Paper.

Lazear, E. P. 2004. Balanced skills and entrepreneurship. American Economic Review 94:20811.

Malmendier, U., and S. Nagel. 2011. Depression babies: Do macroeconomic experiences affect risk-taking? Quarterly Journal of Economics 126:373-416.

Malmendier, U., and G. Tate. 2008. Who makes acquisitions? CEO overconfidence and the market's reaction. Journal of Financial Economics 89:20-43. 
Malmendier, U., G. Tate, and J. Yan. 2011. Overconfidence and early-life experiences: The effect of managerial traits on corporate financial policies. Journal of Finance 66:1687733.

Marquis, C., and A. Tilcsik. 2013. Imprinting: Toward a multilevel theory. Academy of Management Annals 7:193-243.

McEvily, B., J. Jaffee, and M. Tortoriello. 2012. Not all bridging ties are equal: Network imprinting and firm growth in the Nashville legal industry, 1933-1978. Organization Science 23:547-63.

Murphy, K. J., and J. Zabojnik. 2007. Managerial capital and the market for CEOs. Working Paper.

Neal, D. 1999. The complexity of job mobility among young men. Journal of Labor Economics 17:237-61.

Oreopoulos, P., T. von Wachter, and A. Heisz. 2012. The short- and long-term career effects of graduating in a recession. American Economic Journal: Applied Economics 4:1-29.

Oyer, P. 2006. Initial labor market conditions and long-term outcomes for economists. Journal of Economic Perspectives 20:143-60.

- 2008. The making of an investment banker: Stock market shocks, career choice, and lifetime income. Journal of Finance 63:2601-28.

Parrino, R. 1997. CEO turnover and outside succession: A cross-sectional analysis. Journal of Financial Economics 46:165-97.

Pérez-González, F. 2006. Inherited control and firm performance. American Economic Review 96:1559-88.

Schoar, A., and L. Zuo. 2016. Does the market value CEO styles? American Economic Review 106:262-66.

Shu, P. 2012. The long-term impact of business cycles on innovation: Evidence from the Massachusetts Institute of Technology. Working Paper.

- 2015. Are the "best and brightest" going into finance? Career choice and skill development of Massachusetts Institute of Technology Graduates. Working Paper.

Warner, J. B., R. L. Watts, and K. Wruck. 1989. Stock prices and top management changes. Journal of Financial Economics 20:461-92.

Weisbach, M. S. 1995. CEO turnover and the firm’s investment decisions. Journal of Financial Economics 37:159-88.

Yonker, S. E. Forthcoming. Geography and the market for CEOs. Management Science. 
Table 1

Descriptive statistics

\begin{tabular}{lcccc}
\hline \hline & Obs. & Mean & Median & SD \\
\hline Recession & 2,058 & 0.21 & 0.00 & 0.41 \\
Time to CEO & 2,058 & 22.0 & 23.0 & 9.94 \\
Age to CEO & 2,058 & 47.3 & 48.0 & 8.48 \\
Num industries & 2,058 & 1.91 & 2.00 & 0.95 \\
Num firms & 2,058 & 2.57 & 2.00 & 1.55 \\
Num positions & 2,058 & 5.78 & 5.00 & 3.86 \\
Av tenure & 2,058 & 3.15 & 2.00 & 3.28 \\
Founder & 2,058 & 0.10 & 0.00 & 0.30 \\
Banking & 2,058 & 0.15 & 0.00 & 0.36 \\
Military & 2,058 & 0.10 & 0.00 & 0.30 \\
Consulting & 2,058 & 0.08 & 0.00 & 0.26 \\
Law & 2,058 & 0.06 & 0.00 & 0.23 \\
Politics & 2,058 & 0.05 & 0.00 & 0.22 \\
University & 2,058 & 0.03 & 0.00 & 0.17 \\
First private & 2,058 & 0.18 & 0.00 & 0.38 \\
Top ten & 2,058 & 0.09 & 0.00 & 0.29 \\
First sales (\$m) & 2,058 & 3,409 & 714 & 7,754 \\
Sales of firm where CEO (\$m) & 1,566 & 3,117 & 936 & 7,224 \\
ROA of firm where CEO & 1,511 & 0.15 & 0.14 & 0.13 \\
Tobin’s q of firm where CEO & 1,536 & 1.76 & 1.28 & 2.95 \\
CEO first comp. incl. option grants $(\$ 000)$ & 1,049 & 3,299 & 1,678 & 5,346 \\
CEO first comp. incl. options exercised $(\$ 000)$ & 1,064 & 3,088 & 1,206 & 6,291 \\
\hline \hline
\end{tabular}

The dataset is based on a cross-section of individuals who served as CEOs at an Execucomp firm at some point between 1992 and 2010. We collect information on these CEOs' backgrounds and career paths from Biography in Context (formerly Biography Resource Center), Bloomberg, Forbes, and their companies' own proxy filings. We find (some) background information for about $80 \%$ of these Execucomp CEOs. In the reported tests on CEO careers, we only include 2,058 CEOs who have a relatively complete and continuous career profile. The data on sales, ROA, and Tobin's q are obtained from Compustat; compensation data are obtained from Execucomp. All dollar values are converted into 1983 constant dollars. The values of sales and assets are in millions; CEO compensation data are in thousands. See Appendix A for details of the definition and construction of the variables reported in the table. 


\section{Table 2}

\section{Distribution of age at labor market entry}

\begin{tabular}{cccc}
\hline \hline Age & Frequency & Percentage & Cumulative percentage \\
\hline 19 & 12 & 0.7 & 0.7 \\
20 & 17 & 1.1 & 1.8 \\
21 & 57 & 3.5 & 5.3 \\
22 & 151 & 9.4 & 14.7 \\
23 & 197 & 12.2 & 26.9 \\
$\mathbf{2 4}$ & $\mathbf{3 4 2}$ & $\mathbf{2 1 . 2}$ & $\mathbf{4 8 . 1}$ \\
25 & 262 & 16.2 & 64.3 \\
26 & 213 & 13.2 & 77.5 \\
27 & 160 & 9.9 & 87.4 \\
28 & 96 & 5.9 & 93.3 \\
29 & 60 & 3.7 & 97.0 \\
30 & 48 & 3.0 & 100.0 \\
& & & \\
Total & 1,615 & 100 & \\
\hline \hline
\end{tabular}

The sample is the CEO-level dataset as described in Section 1.1 and Table 1. It is important here to base the starting age on the first full-time job that managers had. We do not count internships or short-term jobs as initial job allocations. The number of observations is fewer than that in Table 1 due to missing information on the starting years for some CEOs. 
Table 3

Recession and CEO careers

Panel A: Career path

\begin{tabular}{|c|c|c|c|c|c|c|c|}
\hline & $\begin{array}{c}\text { (1) } \\
\text { Time to CEO }\end{array}$ & $\begin{array}{c}(2) \\
\text { Age to CEO }\end{array}$ & $\begin{array}{c}\text { (3) } \\
\text { Num industries }\end{array}$ & $\begin{array}{c}\text { (4) } \\
\text { Num firms }\end{array}$ & $\begin{array}{c}\text { (5) } \\
\text { Num positions }\end{array}$ & $\begin{array}{c}(6) \\
\text { Av tenure }\end{array}$ & $\begin{array}{c}(7) \\
\text { Foundel }\end{array}$ \\
\hline Recession & $\begin{array}{c}-1.549 * * * \\
(0.550)\end{array}$ & $\begin{array}{c}-0.907 * * \\
(0.449)\end{array}$ & $\begin{array}{c}-0.128 * * \\
(0.052)\end{array}$ & $\begin{array}{c}-0.137 * \\
(0.082)\end{array}$ & $\begin{array}{c}-0.421 * * \\
(0.214)\end{array}$ & $\begin{array}{l}0.367 * \\
(0.193)\end{array}$ & $\begin{array}{c}0.003 \\
(0.017)\end{array}$ \\
\hline Decade FE & Yes & Yes & Yes & Yes & Yes & Yes & Yes \\
\hline Industry FE & Yes & Yes & Yes & Yes & Yes & Yes & Yes \\
\hline Obs. & 2,058 & 2,058 & 2,058 & 2,058 & 2,058 & 2,058 & 2,058 \\
\hline Adj. $R^{2}$ & 0.098 & 0.162 & 0.043 & 0.044 & 0.018 & 0.117 & 0.009 \\
\hline
\end{tabular}

Panel B: Early experience

\begin{tabular}{|c|c|c|c|c|c|c|c|c|c|}
\hline & $\begin{array}{c}(1) \\
\text { Banking }\end{array}$ & $\begin{array}{c}(2) \\
\text { Military }\end{array}$ & $\begin{array}{c}\text { (3) } \\
\text { Consulting }\end{array}$ & $\begin{array}{c}(4) \\
\text { Law }\end{array}$ & $\begin{array}{c}(5) \\
\text { Politics }\end{array}$ & $\begin{array}{c}(6) \\
\text { University }\end{array}$ & $\begin{array}{c}(7) \\
\text { First private }\end{array}$ & $\begin{array}{c}\text { (8) } \\
\text { Top ten }\end{array}$ & $\begin{array}{c}\text { (9) } \\
\text { First sales }\end{array}$ \\
\hline Recession & $\begin{array}{l}-0.007 \\
(0.020)\end{array}$ & $\begin{array}{l}-0.006 \\
(0.016)\end{array}$ & $\begin{array}{c}-0.025 * \\
(0.014)\end{array}$ & $\begin{array}{l}-0.009 \\
(0.012)\end{array}$ & $\begin{array}{l}-0.001 \\
(0.012)\end{array}$ & $\begin{array}{c}0.000 \\
(0.009)\end{array}$ & $\begin{array}{l}0.043 * \\
(0.023)\end{array}$ & $\begin{array}{c}-0.031^{* *} \\
(0.014)\end{array}$ & $\begin{array}{c}-0.290 * * \\
(0.124)\end{array}$ \\
\hline Decade FE & Yes & Yes & Yes & Yes & Yes & Yes & Yes & Yes & Yes \\
\hline Industry FE & No & No & No & No & No & No & No & Yes & Yes \\
\hline Obs. & 2,058 & 2,058 & 2,058 & 2,058 & 2,058 & 2,058 & 2,058 & 2,058 & 2,058 \\
\hline Adj. $R^{2}$ & 0.001 & 0.052 & 0.003 & -0.001 & 0.001 & 0.003 & 0.000 & 0.204 & 0.043 \\
\hline
\end{tabular}

The sample is the CEO-level dataset as described in Section 1.1 and Table 1. See Appendix A for details of the definition and construction of the variables reported in the table. The data on sales are log transformed. Decade fixed effects are based on the decade in which the individual was born. Industry fixed effects are one-digit SIC dummies for the industry in which the individual started her career. Robust standard errors are reported in parentheses. $* * *, * *$, and $*$ denote significance at the $1 \%, 5 \%$, and $10 \%$ levels, respectively. 
Table 4

Recession and type of firm where the manager becomes CEO

\begin{tabular}{|c|c|c|c|c|c|c|c|}
\hline & $\begin{array}{l}\text { (1) } \\
\text { Sales of firm } \\
\text { where CEO }\end{array}$ & $\begin{array}{l}\text { (2) } \\
\text { ROA of firm } \\
\text { where CEO }\end{array}$ & $\begin{array}{c}\text { (3) } \\
\text { Tobin’s q of firm } \\
\text { where CEO }\end{array}$ & $\begin{array}{c}\text { (4) } \\
\text { CEO first comp. } \\
\text { incl. option grants }\end{array}$ & $\begin{array}{c}\text { (5) } \\
\text { CEO first comp. } \\
\text { incl. options exercised }\end{array}$ & $\begin{array}{l}\text { (6) } \\
\text { CEO first comp. } \\
\text { incl. option grants }\end{array}$ & $\begin{array}{c}\text { (7) } \\
\text { CEO first comp. } \\
\text { incl. options exercised }\end{array}$ \\
\hline Recession & $\begin{array}{c}-0.234^{* *} \\
(0.112)\end{array}$ & $\begin{array}{c}0.002 \\
(0.007)\end{array}$ & $\begin{array}{l}-0.290 \\
(0.208)\end{array}$ & $\begin{array}{l}-0.109 \\
(0.080)\end{array}$ & $\begin{array}{c}-0.174 * * \\
(0.088)\end{array}$ & $\begin{array}{l}-0.062 \\
(0.061)\end{array}$ & $\begin{array}{c}-0.112^{*} \\
(0.065)\end{array}$ \\
\hline Assets & & & & & & $\begin{array}{c}0.187 * * * \\
(0.033)\end{array}$ & $\begin{array}{c}0.233^{* * *} \\
(0.034)\end{array}$ \\
\hline Sales & & & & & & $\begin{array}{c}0.229 * * * \\
(0.038)\end{array}$ & $\begin{array}{c}0.226^{* * *} \\
(0.037)\end{array}$ \\
\hline ROA & & & & & & $\begin{array}{c}1.686^{* * *} \\
(0.410)\end{array}$ & $\begin{array}{c}3.790 * * * \\
(0.422)\end{array}$ \\
\hline Decade FE & Yes & Yes & Yes & Yes & Yes & Yes & Yes \\
\hline Industry FE & Yes & Yes & Yes & Yes & Yes & Yes & Yes \\
\hline Obs. & 1,566 & 1,511 & 1,536 & 1,049 & 1,064 & 1,049 & 1,064 \\
\hline Adj. $R^{2}$ & 0.021 & 0.034 & 0.018 & 0.025 & 0.023 & 0.392 & 0.454 \\
\hline
\end{tabular}

The sample is the CEO-level dataset as described in Section 1.1 and Table 1. See Appendix A for details of the definition and construction of the variables reported in the table. The data on sales, assets, and CEO compensation are all log-transformed. Decade fixed effects are based on the decade in which the individual was born. Industry fixed effects are one-digit SIC dummies for the industry in which the individual started her career. Robust standard errors are reported in parentheses. ${ }^{* * *},{ }^{* *}$, and $*$ denote significance at the $1 \%, 5 \%$, and $10 \%$ levels, respectively. 
Table 5

The first job's impact

Panel A: Career path

\begin{tabular}{|c|c|c|c|c|c|c|c|}
\hline & $\begin{array}{c}\text { (1) } \\
\text { Time to CEO }\end{array}$ & $\begin{array}{c}\text { (2) } \\
\text { Age to CEO }\end{array}$ & $\begin{array}{c}\text { (3) } \\
\text { Num industries }\end{array}$ & $\begin{array}{c}\text { (4) } \\
\text { Num firms }\end{array}$ & $\begin{array}{c}\text { (5) } \\
\text { Num positions }\end{array}$ & $\begin{array}{c}(6) \\
\text { Av tenure }\end{array}$ & $\begin{array}{c}(7) \\
\text { Founder }\end{array}$ \\
\hline Recession & $\begin{array}{c}-1.191^{* *} \\
(0.526)\end{array}$ & $\begin{array}{c}-0.741^{*} \\
(0.440)\end{array}$ & $\begin{array}{c}-0.093^{*} \\
(0.049)\end{array}$ & $\begin{array}{l}-0.099 \\
(0.079)\end{array}$ & $\begin{array}{l}-0.288 \\
(0.207)\end{array}$ & $\begin{array}{c}0.277 \\
(0.188)\end{array}$ & $\begin{array}{l}-0.007 \\
(0.017)\end{array}$ \\
\hline First sales & $\begin{array}{c}1.041^{* * *} \\
(0.095)\end{array}$ & $\begin{array}{c}0.550 * * * \\
(0.079)\end{array}$ & $\begin{array}{c}0.117^{* * * *} \\
(0.009)\end{array}$ & $\begin{array}{c}0.152^{* * *} \\
(0.016)\end{array}$ & $\begin{array}{c}0.466 * * * \\
(0.038)\end{array}$ & $\begin{array}{c}-0.284^{* * *} \\
(0.031)\end{array}$ & $\begin{array}{c}-0.030 * * * \\
(0.004)\end{array}$ \\
\hline First private & $\begin{array}{c}-2.091 * * * \\
(0.649)\end{array}$ & $\begin{array}{l}-0.214 \\
(0.549)\end{array}$ & $\begin{array}{l}-0.016 \\
(0.061)\end{array}$ & $\begin{array}{l}0.203^{*} \\
(0.114)\end{array}$ & $\begin{array}{c}0.064 \\
(0.265)\end{array}$ & $\begin{array}{c}0.293 \\
(0.205)\end{array}$ & $\begin{array}{c}0.060 * * * \\
(0.021)\end{array}$ \\
\hline Decade FE & Yes & Yes & Yes & Yes & Yes & Yes & Yes \\
\hline Industry FE & Yes & Yes & Yes & Yes & Yes & Yes & Yes \\
\hline Obs. & 2,058 & 2,058 & 2,058 & 2,058 & 2,058 & 2,058 & 2,058 \\
\hline Adj. $R^{2}$ & 0.154 & 0.182 & 0.116 & 0.091 & 0.087 & 0.153 & 0.060 \\
\hline
\end{tabular}


Panel B: Type of firm where the manager becomes CEO

\begin{tabular}{|c|c|c|c|c|c|c|c|}
\hline & $\begin{array}{c}\text { (1) } \\
\text { Sales of firm } \\
\text { where CEO }\end{array}$ & $\begin{array}{l}\text { (2) } \\
\text { ROA of firm } \\
\text { where CEO }\end{array}$ & $\begin{array}{c}\text { (3) } \\
\text { Tobin’s q of firm } \\
\text { where CEO }\end{array}$ & $\begin{array}{c}\text { (4) } \\
\text { CEO first comp. } \\
\text { incl. option grants }\end{array}$ & $\begin{array}{c}\text { (5) } \\
\text { CEO first comp. } \\
\text { incl. options exercised }\end{array}$ & $\begin{array}{c}\text { (6) } \\
\text { CEO first comp. } \\
\text { incl. option grants }\end{array}$ & $\begin{array}{c}\text { (7) } \\
\text { CEO first comp. } \\
\text { incl. options exercised }\end{array}$ \\
\hline Recession & $\begin{array}{l}-0.120 \\
(0.103)\end{array}$ & $\begin{array}{c}0.000 \\
(0.007)\end{array}$ & $\begin{array}{c}-0.292 \\
(0.199)\end{array}$ & $\begin{array}{l}-0.081 \\
(0.078)\end{array}$ & $\begin{array}{c}-0.144^{*} \\
(0.087)\end{array}$ & $\begin{array}{l}-0.061 \\
(0.061)\end{array}$ & $\begin{array}{c}-0.115^{*} \\
(0.065)\end{array}$ \\
\hline First sales & $\begin{array}{c}0.329 * * * \\
(0.024)\end{array}$ & $\begin{array}{c}-0.004^{*} \\
(0.002)\end{array}$ & $\begin{array}{c}0.002 \\
(0.035)\end{array}$ & $\begin{array}{c}0.096 * * * \\
(0.017)\end{array}$ & $\begin{array}{c}0.094^{* * *} \\
(0.019)\end{array}$ & $\begin{array}{c}0.004 \\
(0.014)\end{array}$ & $\begin{array}{l}-0.011 \\
(0.015)\end{array}$ \\
\hline First private & $\begin{array}{c}-0.280 * * \\
(0.124)\end{array}$ & $\begin{array}{l}0.018 * \\
(0.011)\end{array}$ & $\begin{array}{c}0.149 \\
(0.128)\end{array}$ & $\begin{array}{l}-0.030 \\
(0.104)\end{array}$ & $\begin{array}{l}-0.049 \\
(0.112)\end{array}$ & $\begin{array}{l}-0.020 \\
(0.079)\end{array}$ & $\begin{array}{l}-0.039 \\
(0.085)\end{array}$ \\
\hline Assets & & & & & & $\begin{array}{c}0.186^{* * *} \\
(0.033)\end{array}$ & $\begin{array}{c}0.234^{* * *} \\
(0.034)\end{array}$ \\
\hline Sales & & & & & & $\begin{array}{c}0.228^{* * *} \\
(0.038)\end{array}$ & $\begin{array}{c}0.229 * * * \\
(0.038)\end{array}$ \\
\hline ROA & & & & & & $\begin{array}{c}1.689 * * * \\
(0.411)\end{array}$ & $\begin{array}{c}3.785 * * * \\
(0.422)\end{array}$ \\
\hline Decade FE & Yes & Yes & Yes & Yes & Yes & Yes & Yes \\
\hline Industry FE & Yes & Yes & Yes & Yes & Yes & Yes & Yes \\
\hline Obs. & 1,566 & 1,511 & 1,536 & 1,049 & 1,064 & 1,049 & 1,064 \\
\hline Adj. $R^{2}$ & 0.187 & 0.039 & 0.017 & 0.058 & 0.049 & 0.391 & 0.453 \\
\hline
\end{tabular}

The sample is the CEO-level dataset as described in Section 1.1 and Table 1. See Appendix A for details of the definition and construction of the variables reported in the table. The data on sales, assets, and CEO compensation are all log-transformed. Decade fixed effects are based on the decade in which the individual was born. Industry fixed effects are one-digit SIC dummies for the industry in which the individual started her career. Robust standard errors are reported in parentheses. ***, **, and * denote significance at the $1 \%, 5 \%$, and $10 \%$ levels, respectively. 
Table 6

\section{Recession and management styles}

\begin{tabular}{|c|c|c|c|c|c|c|c|c|c|c|}
\hline & $\begin{array}{c}(1) \\
\text { Capex }\end{array}$ & $\begin{array}{c}(2) \\
R \& D\end{array}$ & $\begin{array}{c}(3) \\
\text { SG\&A }\end{array}$ & $\begin{array}{c}(4) \\
\text { Leverage }\end{array}$ & $\begin{array}{c}(5) \\
\text { Working } \\
\text { capital } \\
\end{array}$ & $\begin{array}{c}\text { (6) } \\
\text { Sales } \\
\text { growth }\end{array}$ & $\begin{array}{c}(7) \\
\text { Effective } \\
\text { tax rate }\end{array}$ & $\begin{array}{c}\text { (8) } \\
\text { Return } \\
\text { volatility }\end{array}$ & $\begin{array}{c}(9) \\
\mathrm{ROA}\end{array}$ & $\begin{array}{c}(10) \\
\text { OROA }\end{array}$ \\
\hline Recession & $\begin{array}{c}-0.004 * * \\
(0.002)\end{array}$ & $\begin{array}{c}-0.004^{* * *} \\
(0.001)\end{array}$ & $\begin{array}{c}-0.012 * * \\
(0.006)\end{array}$ & $\begin{array}{c}-0.008 * * \\
(0.004)\end{array}$ & $\begin{array}{c}-0.018^{* * *} \\
(0.007)\end{array}$ & $\begin{array}{c}-0.016^{* * *} \\
(0.006)\end{array}$ & $\begin{array}{c}0.017 * * * \\
(0.006)\end{array}$ & $\begin{array}{c}-0.040 * * * \\
(0.010)\end{array}$ & $\begin{array}{l}-0.002 \\
(0.003)\end{array}$ & $\begin{array}{l}-0.002 \\
(0.003)\end{array}$ \\
\hline Decade FE & Yes & Yes & Yes & Yes & Yes & Yes & Yes & Yes & Yes & Yes \\
\hline Firm FE & Yes & Yes & Yes & Yes & Yes & Yes & Yes & Yes & Yes & Yes \\
\hline Industry-year FE & Yes & Yes & Yes & Yes & Yes & Yes & Yes & Yes & Yes & Yes \\
\hline Obs. & 34,353 & 36,266 & 36,244 & 35,501 & 36,086 & 36,718 & 32,529 & 35,374 & 36,161 & 36,240 \\
\hline Adj. $R^{2}$ & 0.420 & 0.664 & 0.677 & 0.559 & 0.494 & 0.167 & 0.162 & 0.507 & 0.484 & 0.380 \\
\hline
\end{tabular}

The sample is a firm-year level dataset covering a given firm over the years a given individual was the CEO of that firm. We only include CEOs who were in that position at that firm for at least three years; we exclude CEOs of financial, insurance, and real estate firms, as well as CEOs of regulated utilities. Our final sample includes 4,152 CEOs. Financial information for these firm-year observations is obtained from Compustat, and the data on stock returns from CRSP. Included controls are as follows: column (1): cash flows, lagged Tobin's q, and sales growth; columns (2) and (3): cash flows, ROA, and sales growth; column (4): cash flows, ROA, lagged assets, and sales growth; column (5): cash flows, ROA, and sales growth; column (7): tax loss carry-forward (TLCF), lagged assets, and sales growth; column (8): sales growth; columns (9) and (10): sales and sales growth. See Appendix A for details of the definition and construction of the variables reported in the table; summary statistics are presented in Table B4 in Appendix B. Decade fixed effects are based on the decade in which the CEO was born. Robust standard errors clustered at the firm level are reported in parentheses. ***, **, and * denote significance at the $1 \%$, $5 \%$, and $10 \%$ levels, respectively. 
Table 7

Recession and management styles (bootstrapping)

Panel A: Distribution of $t$-statistics on the pseudo recession CEO indicator

\begin{tabular}{|c|c|c|c|c|c|c|c|c|c|c|c|c|c|}
\hline & \multicolumn{13}{|c|}{$T$-statistics on the pseudo recession CEO indicator } \\
\hline & Mean & $\mathrm{SD}$ & Min & $\mathrm{P} 1$ & P5 & P10 & P25 & P50 & P75 & $\mathrm{P} 90$ & P95 & P99 & Max \\
\hline Capex & -0.04 & 0.95 & -3.61 & -2.20 & -1.59 & -1.24 & -0.70 & -0.04 & 0.60 & 1.19 & 1.54 & 2.15 & 2.80 \\
\hline $\mathrm{R} \& \mathrm{D}$ & 0.01 & 0.95 & -3.62 & -2.24 & -1.52 & -1.21 & -0.64 & 0.01 & 0.63 & 1.23 & 1.55 & 2.29 & 3.01 \\
\hline SG\&A & 0.03 & 0.98 & -2.84 & -2.29 & -1.68 & -1.29 & -0.59 & 0.07 & 0.66 & 1.25 & 1.60 & 2.19 & 3.32 \\
\hline Leverage & -0.03 & 0.98 & -2.80 & -2.35 & -1.64 & -1.32 & -0.71 & -0.02 & 0.62 & 1.18 & 1.62 & 2.35 & 3.08 \\
\hline Working capital & 0.04 & 0.97 & -3.29 & -2.25 & -1.61 & -1.28 & -0.60 & 0.10 & 0.72 & 1.26 & 1.52 & 2.16 & 3.07 \\
\hline Sales growth & 0.04 & 0.96 & -2.67 & -2.25 & -1.56 & -1.17 & -0.64 & 0.05 & 0.63 & 1.32 & 1.67 & 2.30 & 2.98 \\
\hline Effective tax rate & -0.03 & 0.96 & -2.78 & -2.36 & -1.66 & -1.31 & -0.65 & 0.01 & 0.63 & 1.18 & 1.52 & 2.17 & 2.89 \\
\hline Return volatility & 0.01 & 0.97 & -2.74 & -2.20 & -1.56 & -1.23 & -0.64 & 0.03 & 0.61 & 1.24 & 1.55 & 2.34 & 3.72 \\
\hline ROA & 0.00 & 1.00 & -3.47 & -2.43 & -1.66 & -1.33 & -0.67 & 0.03 & 0.67 & 1.28 & 1.65 & 2.14 & 2.73 \\
\hline OROA & -0.01 & 0.99 & -3.67 & -2.26 & -1.67 & -1.28 & -0.66 & 0.00 & 0.67 & 1.30 & 1.61 & 2.25 & 2.84 \\
\hline
\end{tabular}

Panel B: Actual $t$-statistics and the associated $p$-values inferred from the distribution of $t$-statistics on the pseudo recession CEO indicator

\begin{tabular}{lcc}
\hline & Actual $t$-statistics & $p$-value (one-sided) \\
\cline { 2 - 3 } Capex & -2.53 & 0.005 \\
R\&D & -2.96 & 0.002 \\
SG\&A & -2.06 & 0.019 \\
Leverage & -2.05 & 0.007 \\
Working capital & -2.70 & 0.032 \\
Sales growth & -2.66 & 0.002 \\
Effective tax rate & 3.06 & 0.001 \\
Return volatility & -4.15 & 0.000 \\
ROA & -0.63 & 0.000 \\
OROA & -0.73 & 0.003 \\
& & 0.004 \\
\hline
\end{tabular}


We create a pseudo recession CEO indicator, where the probability of drawing a one is $18.8 \%$ (i.e., the actual percentage of recession CEOs in the sample) and the probability of drawing a zero is $81.2 \%$, then run the same regressions in Table 6 with this pseudo recession CEO indicator (rather than the actual recession CEO dummy). We repeat this exercise 1,000 times. Panel A reports the distribution of $t$-statistics on the pseudo recession CEO indicator based on 1,000 simulations. Panel B reports the actual $t$-statistics (based on the actual recession CEO dummy) and the associated $p$-values inferred from the empirical distributions reported in Panel A. For example, the actual $t$-statistic on the recession CEO dummy is -2.53 when the dependent variable is capital investment. Out of the 1,000 simulations, five simulations generate $t$-statistics less than this number, and seven simulations generate $t$-statistics whose absolute value exceeds 2.53. Thus, the one-sided $p$-value is 0.005 and the two-sided $p$-value is 0.007 . 


\section{Appendix A \\ Variable definitions}

Table A1

Variables related to CEO careers

Recession

Time to CEO

Age to CEO

Num industries

Num firms

Num positions

Av tenure

Founder

Banking

Military

Consulting

Law

Politics

University

First private

Top ten

First sales

Sales of firm where

CEO

ROA of firm where CEO

Tobin's q of firm where CEO

CEO first comp. incl. option grants

CEO first comp. incl. options exercised
A dummy for whether the individual's first job begins during a recession.

Number of years between the start of an individual's career and her first becoming CEO.

Age at which the individual first becomes CEO.

Number of industries in which a manager was employed before first becoming CEO.

Number of firms in which a manager was employed before first becoming CEO.

Number of positions the individual held before first becoming CEO.

Number of years a manager stays in a given position, averaged over all positions before first becoming CEO.

A dummy for whether the CEO is the founder of the firm.

A dummy for whether the individual had any experience in a banking firm before first becoming CEO.

A dummy for whether the individual had any military experience before first becoming CEO.

A dummy for whether the individual had any experience at a consulting firm before first becoming CEO.

A dummy for whether the individual had any experience at a law firm before first becoming CEO.

A dummy for whether the individual held any political office before first becoming CEO.

A dummy for whether the individual had any academic experience before first becoming CEO.

A dummy for whether the individual's first job is at a private firm.

A dummy for whether the individual's first job is at a firm that ranks in the top ten firms, in terms of companies known for producing CEOs (i.e., IBM, GE, P\&G, Arthur Andersen, Ford, GM, AT\&T, McKinsey, Texas Instruments, and DuPont).

Sales of the first public firm where the individual worked, measured in the year the individual joined the firm.

Sales of the firm where the manager becomes CEO, measured in the year before the CEO starts the position.

ROA of the firm where the manager becomes CEO, measured in the year before the CEO starts the position.

Tobin's q of the firm where the manager becomes CEO, measured in the year before the CEO starts the position.

Total value of a manager's compensation package, including option grants, for the year when the manager becomes CEO (tdc1).

Total value of a manager's compensation package, including options exercised, for the year when the manager becomes CEO (tdc2). 
Table A2

Variables related to CEO management styles

\begin{tabular}{|c|c|}
\hline Capex & Capital expenditures (capx) over lagged total assets (at). \\
\hline $\mathrm{R} \& \mathrm{D}$ & $\begin{array}{l}\text { R\&D expenditures ( } x r d) \text { over lagged total assets (at); as in other studies (e.g., } \\
\text { Coles, Daniel, and Naveen 2006), we set R\&D equal to } 0 \text { when it is missing from } \\
\text { Compustat. }\end{array}$ \\
\hline SG\&A & Selling, general, and administrative expenses (xsga) over lagged total assets (at). \\
\hline Leverage & $\begin{array}{l}\text { Long-term debt }(d l t t) \text { plus debt in current liabilities }(d l c) \text { over the market value of } \\
\text { assets, where the market value of assets equals the book value of assets (at) plus } \\
\text { the market value of common equity ( } p r c c \_f \times c s h o \text { ) less the sum of the book value } \\
\text { of common equity }(c e q) \text { and balance sheet deferred taxes }(t x d b) \text {. }\end{array}$ \\
\hline Working capital & Current assets (act) minus current liabilities (lct) over lagged total assets (at). \\
\hline Sales growth & Current sales (sale) over lagged sales (sale) minus one. \\
\hline Effective tax rate & $\begin{array}{l}\text { Cash tax paid (txpd) over pre-tax book income (pi) before special items (spi); } \\
\text { effective tax rates with negative pre-tax income before special items are set to } \\
\text { missing; the remaining non-missing effective tax rates are winsorized (reset) so } \\
\text { that the largest observation is } 1 \text { and the smallest is } 0 \text {. }\end{array}$ \\
\hline Return volatility & $\begin{array}{l}\text { Natural logarithm of the standard deviation of daily stock returns over the fiscal } \\
\text { year. }\end{array}$ \\
\hline ROA & $\begin{array}{l}\text { Earnings before depreciation, interest, and tax (ebitda) over lagged total assets } \\
\text { (at). }\end{array}$ \\
\hline OROA & Cash flow $(i b+d p)$ over lagged total assets $(a t)$. \\
\hline Assets & Natural logarithm of total assets (at). \\
\hline Sales & Natural logarithm of sales (sale). \\
\hline Cash flows & $\begin{array}{l}\text { The sum of earnings before extraordinary items (ib) and depreciation }(d p) \text { over } \\
\text { lagged total assets (at). }\end{array}$ \\
\hline Tobin’s q & $\begin{array}{l}\text { The market value of assets }\left(a t+p r c c \_f \times c s h o-c e q-t x d b\right) \text { divided by the book } \\
\text { value of assets }(a t) \text {. }\end{array}$ \\
\hline TLCF & A dummy for whether the firm has a positive value of tax loss carry-forward (tlcf). \\
\hline
\end{tabular}




\section{Appendix B \\ Additional Tables}

Table B1

Univariate statistics on the overall differences between recession and non-recession CEOs

\begin{tabular}{|c|c|c|c|c|c|}
\hline & \multicolumn{2}{|c|}{ Recession CEOs } & \multicolumn{2}{|c|}{ Non-recession CEOs } & \multirow{2}{*}{ Differences } \\
\hline & Obs. & Mean & Obs. & Mean & \\
\hline Time to CEO & 438 & 20.8 & 1,620 & 22.3 & $-1.6^{* * *}$ \\
\hline Age to CEO & 438 & 46.4 & 1,620 & 47.6 & $-1.2^{* * *}$ \\
\hline Num industries & 438 & 1.80 & 1,620 & 1.94 & $-0.15^{* * *}$ \\
\hline Num firms & 438 & 2.44 & 1,620 & 2.60 & $-0.16 *$ \\
\hline Num positions & 438 & 5.50 & 1,620 & 5.85 & $-0.36^{*}$ \\
\hline Av tenure & 438 & 3.29 & 1,620 & 3.11 & 0.18 \\
\hline Founder & 438 & 0.10 & 1,620 & 0.10 & -0.01 \\
\hline Banking & 438 & 0.14 & 1,620 & 0.15 & -0.01 \\
\hline Military & 438 & 0.09 & 1,620 & 0.10 & -0.02 \\
\hline Consulting & 438 & 0.05 & 1,620 & 0.08 & $-0.03^{*}$ \\
\hline Law & 438 & 0.05 & 1,620 & 0.06 & -0.01 \\
\hline Politics & 438 & 0.05 & 1,620 & 0.05 & 0.00 \\
\hline University & 438 & 0.03 & 1,620 & 0.03 & -0.01 \\
\hline First private & 438 & 0.21 & 1,620 & 0.17 & $0.04^{*}$ \\
\hline Top ten & 438 & 0.06 & 1,620 & 0.10 & $-0.04 * *$ \\
\hline First sales $(\$ m)$ & 438 & 2,963 & 1,620 & 3,529 & -567 \\
\hline Sales of firm where CEO (\$m) & 335 & 2,902 & 1,231 & 3,176 & -273 \\
\hline ROA of firm where CEO & 320 & 0.14 & 1,191 & 0.15 & 0.00 \\
\hline Tobin’s q of firm where CEO & 327 & 1.59 & 1,209 & 1.81 & -0.22 \\
\hline CEO first comp. incl. option grants (\$000) & 234 & 2,959 & 815 & 3,396 & -437 \\
\hline CEO first comp. incl. options exercised (\$000) & 238 & 2,941 & 826 & 3,131 & -189 \\
\hline
\end{tabular}

The sample is the CEO-level dataset as described in Section 1.1 and Table 1. We perform a two-tailed $t$-test of differences in means. $* * *, * *$, and $*$ denote significance at the $1 \%, 5 \%$, and $10 \%$ levels, respectively. See Appendix A for details of the definition and construction of the variables reported in the table. 
Table B2

Recession and CEO career path (larger sample)

\begin{tabular}{lcc}
\hline \hline & $(1)$ & $(2)$ \\
& Time to CEO & Age to CEO \\
\hline & & $-0.613^{* *}$ \\
Recession & $-0.910^{* * *}$ & $(0.244)$ \\
& $(0.284)$ & \\
Decade FE & & Yes \\
Industry FE & Yes & Yes \\
Obs. & Yes & 5,312 \\
Adj. $R^{2}$ & 5,312 & 0.262 \\
\hline \hline
\end{tabular}

The sample is the entire CEO-level dataset as described in Section 1.1. See Appendix A for details of the definition and construction of the variables reported in the table. Decade fixed effects are based on the decade in which the individual was born. Industry fixed effects are one-digit SIC dummies for the industry in which the individual started her career. Robust standard errors are reported in parentheses. ${ }^{* * *}, * *$, and $*$ denote significance at the $1 \%$, $5 \%$, and $10 \%$ levels, respectively. 
Table B3

Recession and type of firm where the manager becomes CEO (larger sample)

\begin{tabular}{|c|c|c|c|c|c|c|c|}
\hline & $\begin{array}{c}\text { (1) } \\
\text { Sales of firm } \\
\text { where CEO }\end{array}$ & $\begin{array}{l}\text { (2) } \\
\text { ROA of firm } \\
\text { where CEO }\end{array}$ & $\begin{array}{l}\text { (3) } \\
\text { Tobin’s q of firm } \\
\text { where CEO }\end{array}$ & $\begin{array}{l}\text { (4) } \\
\text { CEO first comp. } \\
\text { incl. option grants }\end{array}$ & $\begin{array}{c}\text { (5) } \\
\text { CEO first comp. } \\
\text { incl. options exercised }\end{array}$ & $\begin{array}{c}\text { (6) } \\
\text { CEO first comp. } \\
\text { incl. Option Grants }\end{array}$ & $\begin{array}{c}\text { (7) } \\
\text { CEO first comp. } \\
\text { incl. options exercised }\end{array}$ \\
\hline Recession & $\begin{array}{c}-0.134^{* *} \\
(0.061)\end{array}$ & $\begin{array}{c}0.002 \\
(0.004)\end{array}$ & $\begin{array}{l}-0.081 \\
(0.075)\end{array}$ & $\begin{array}{c}0.018 \\
(0.044)\end{array}$ & $\begin{array}{c}-0.085 * \\
(0.045)\end{array}$ & $\begin{array}{c}0.023 \\
(0.033)\end{array}$ & $\begin{array}{c}-0.073 * * \\
(0.034)\end{array}$ \\
\hline Assets & & & & & & $\begin{array}{c}0.194 * * * \\
(0.022)\end{array}$ & $\begin{array}{c}0.187 * * * \\
(0.022)\end{array}$ \\
\hline Sales & & & & & & $\begin{array}{c}0.236 * * * \\
(0.023)\end{array}$ & $\begin{array}{c}0.235^{* * *} \\
(0.023)\end{array}$ \\
\hline ROA & & & & & & $\begin{array}{c}1.003 * * * \\
(0.168)\end{array}$ & $\begin{array}{c}2.256 * * * \\
(0.170)\end{array}$ \\
\hline Decade FE & Yes & Yes & Yes & Yes & Yes & Yes & Yes \\
\hline Industry FE & Yes & Yes & Yes & Yes & Yes & Yes & Yes \\
\hline Obs. & 4,808 & 4,566 & 4,322 & 3,414 & 3,453 & 3,414 & 3,453 \\
\hline Adj. $R^{2}$ & 0.048 & 0.050 & 0.032 & 0.032 & 0.034 & 0.427 & 0.437 \\
\hline
\end{tabular}

The sample is the entire CEO-level dataset as described in Section 1.1. See Appendix A for details of the definition and construction of the variables reported in the table. The data on sales, assets, and CEO compensation are all log-transformed. Decade fixed effects are based on the decade in which the individual was born. Industry fixed effects are one-digit SIC dummies for the industry in which the individual started her career. Robust standard errors are reported in parentheses. ***, **, and * denote significance at the $1 \%, 5 \%$, and $10 \%$ levels, respectively. 
Table B4

Summary statistics of variables related to CEO management styles

\begin{tabular}{lcccc}
\hline \hline & Obs. & Mean & Median & SD \\
\hline Recession & 36,718 & 0.188 & 0.000 & 0.391 \\
Capex & 34,353 & 0.080 & 0.056 & 0.084 \\
R\&D & 36,266 & 0.037 & 0.000 & 0.071 \\
SG\&A & 36,244 & 0.294 & 0.238 & 0.263 \\
Leverage & 35,501 & 0.161 & 0.125 & 0.154 \\
Working capital & 36,086 & 0.281 & 0.246 & 0.348 \\
Sales growth & 36,718 & 0.158 & 0.106 & 0.262 \\
Effective tax rate & 32,529 & 0.219 & 0.211 & 0.206 \\
Return volatility & 35,374 & -3.666 & -3.687 & 0.440 \\
ROA & 36,161 & 0.173 & 0.162 & 0.130 \\
OROA & 36,240 & 0.111 & 0.110 & 0.112 \\
\hline \hline
\end{tabular}

The sample is a firm-year-level dataset covering a given firm over the years a given individual was the CEO of that firm. We only include CEOs who were in that position at that firm for at least three years; we exclude CEOs of financial, insurance, and real estate firms, as well as CEOs of regulated utilities. Our final sample includes 4,152 CEOs. Financial information for these firm-year observations is obtained from Compustat, and the data on stock returns from CRSP. See Appendix A for details of the definition and construction of the variables reported in the table. 
Table B5

Depth of recession and management styles

\begin{tabular}{|c|c|c|c|c|c|c|c|c|c|c|}
\hline & $\begin{array}{c}(1) \\
\text { Capex }\end{array}$ & $\begin{array}{c}(2) \\
R \& D\end{array}$ & $\begin{array}{c}\text { (3) } \\
\text { SG\&A }\end{array}$ & $\begin{array}{c}\text { (4) } \\
\text { Leverage }\end{array}$ & $\begin{array}{c}(5) \\
\text { Working } \\
\text { capital } \\
\end{array}$ & $\begin{array}{c}\text { (6) } \\
\text { Sales } \\
\text { growth }\end{array}$ & $\begin{array}{c}(7) \\
\text { Effective } \\
\text { tax rate }\end{array}$ & $\begin{array}{c}(8) \\
\text { Return } \\
\text { volatility }\end{array}$ & $\begin{array}{c}(9) \\
\text { ROA }\end{array}$ & $\begin{array}{c}(10) \\
\text { OROA }\end{array}$ \\
\hline Depth_Recession & $\begin{array}{c}-0.005^{* *} \\
(0.002)\end{array}$ & $\begin{array}{c}-0.005^{* * *} \\
(0.002)\end{array}$ & $\begin{array}{c}-0.017 * * \\
(0.008)\end{array}$ & $\begin{array}{c}-0.010 * * \\
(0.005)\end{array}$ & $\begin{array}{c}-0.023^{* *} \\
(0.009)\end{array}$ & $\begin{array}{c}-0.021 * * * \\
(0.008)\end{array}$ & $\begin{array}{c}0.018 * * \\
(0.007)\end{array}$ & $\begin{array}{c}-0.052 * * * \\
(0.012)\end{array}$ & $\begin{array}{l}-0.002 \\
(0.004)\end{array}$ & $\begin{array}{l}-0.003 \\
(0.004)\end{array}$ \\
\hline Decade FE & Yes & Yes & Yes & Yes & Yes & Yes & Yes & Yes & Yes & Yes \\
\hline Firm FE & Yes & Yes & Yes & Yes & Yes & Yes & Yes & Yes & Yes & Yes \\
\hline Industry-year FE & Yes & Yes & Yes & Yes & Yes & Yes & Yes & Yes & Yes & Yes \\
\hline Obs. & 34,353 & 36,266 & 36,244 & 35,501 & 36,086 & 36,718 & 32,529 & 35,374 & 36,161 & 36,240 \\
\hline Adj. $R^{2}$ & 0.420 & 0.664 & 0.677 & 0.559 & 0.494 & 0.166 & 0.162 & 0.507 & 0.485 & 0.380 \\
\hline
\end{tabular}

Depth_Recession is defined as the number of months the recession lasted (rescaled to range from 0 to 1 ). The sample is a firm-year-level dataset covering a given firm over the years a given individual was the CEO of that firm. We only include CEOs who were in that position at that firm for at least three years; we exclude CEOs of financial, insurance, and real estate firms, as well as CEOs of regulated utilities. Our final sample includes 4,152 CEOs. Financial information for these firm-year observations is obtained from Compustat, and the data on stock returns from CRSP. Included controls are as follows: column (1): cash flows, lagged Tobin's q, and sales growth; columns (2) and (3): cash flows, ROA, and sales growth; column (4): cash flows, ROA, lagged assets, and sales growth; column (5): cash flows, ROA, and sales growth; column (7): tax loss carry-forward (TLCF), lagged assets, and sales growth; column (8): sales growth; columns (9) and (10): sales and sales growth. See Appendix A for details of the definition and construction of the variables reported in the table; summary statistics are presented in Table B4 in Appendix B. Decade fixed effects are based on the decade in which the CEO was born. Robust standard errors clustered at the firm level are reported in parentheses. $* * *, * *$, and $*$ denote significance at the $1 \%, 5 \%$, and $10 \%$ levels, respectively. 